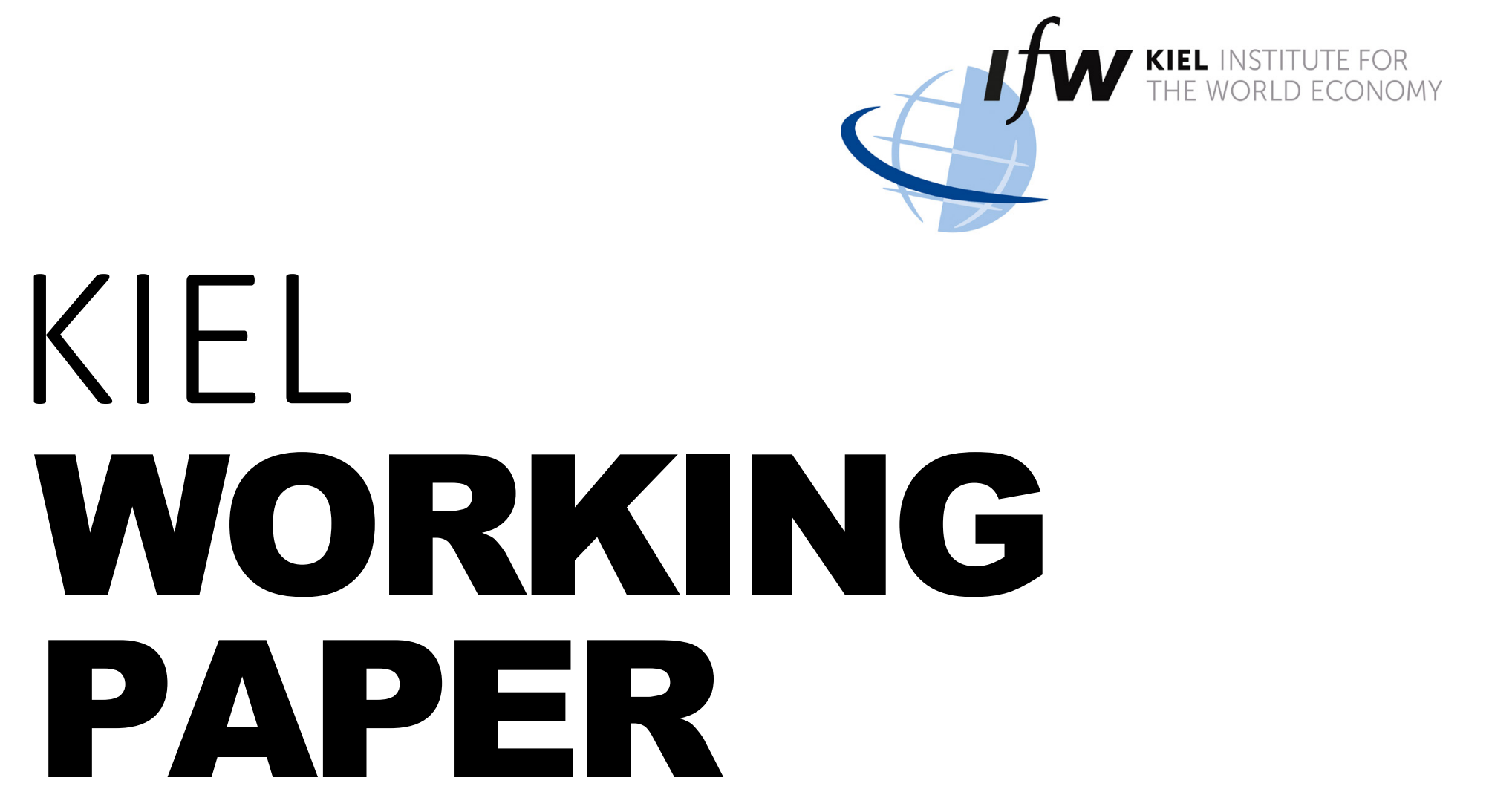

\title{
Employment
}

Protection and Firm Relocation: Theory and Evidence

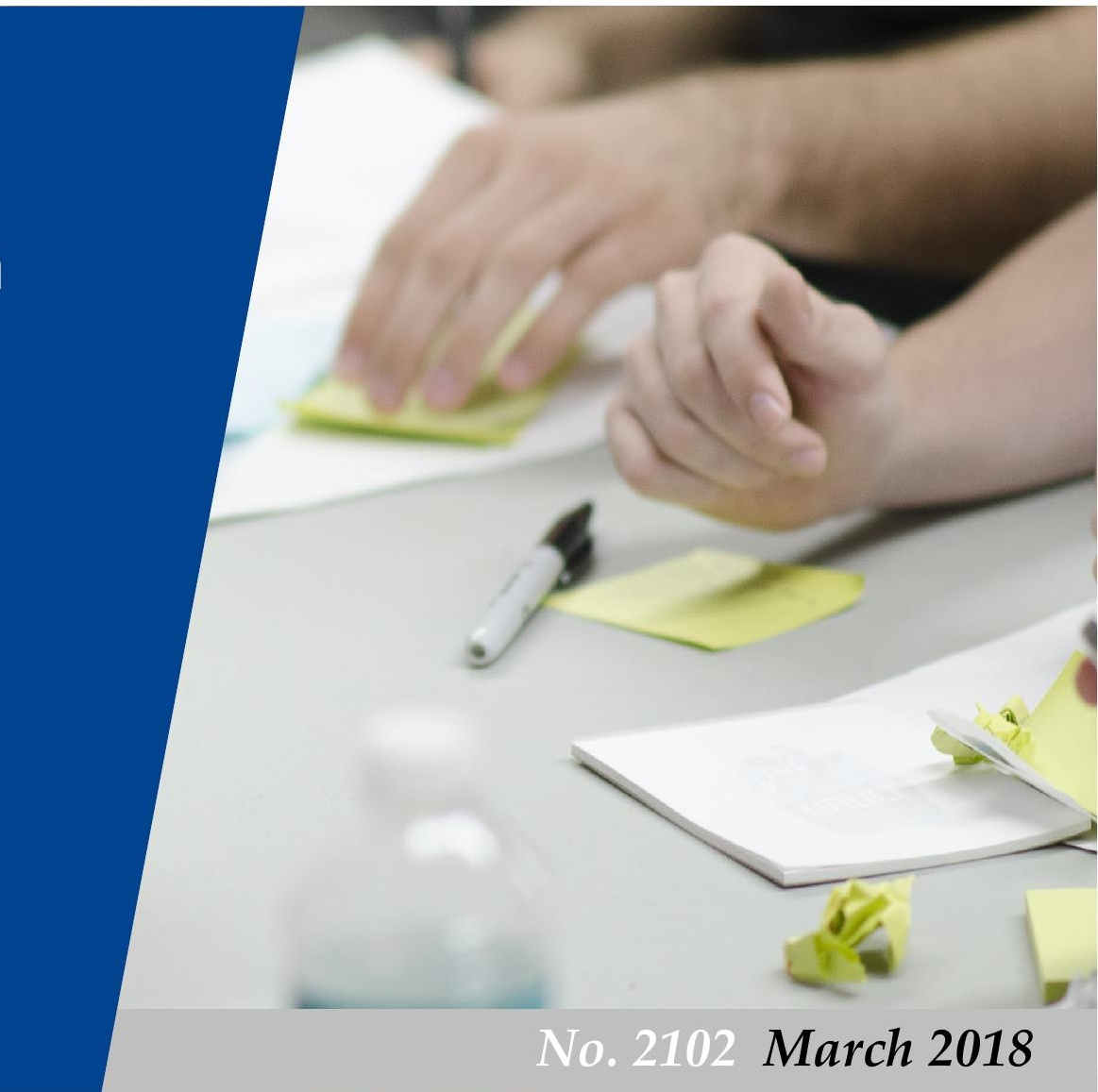

Gerda Dewit, Holger Görg and Yama Temouri 


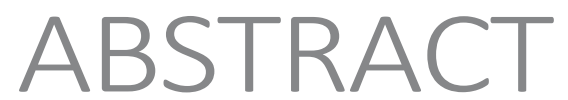

\section{EMPLOYMENT PROTECTION AND FIRM RELOCATION: THEORY AND EVIDENCE*}

\section{Gerda Dewit, Holger Görg and Yama Temouri}

We examine the determinants of the decision to relocate activities abroad for firms located in OECD countries. We argue that particular firm-specific features play a crucial role for the link between employment protection and relocation. Stricter employment protection laws in the current production location discourage firms' relocation abroad. While larger, more productive firms and firms with higher labour intensities have, ceteris paribus, higher propensities to relocate, they also face higher exit barriers if the country from which they consider relocating has strict employment protection laws. Our predictions are supported empirically, using firm level data for 28 OECD countries.

Keywords: Employment Protection, Relocation, Multinational Enterprises

JEL classification: F23, L23, J88

\section{Gerda Dewit}

National University of Ireland

Maynooth

Co. Kildare,

Ireland.

Email: gerda.dewit@mu.ie

www.maynoothuniversity.ie

\section{Holger Görg}

Kiel Centre for Globalization at the Kiel Institute for the World Economy

Kiellinie 66

D-24105 Kiel, Germany

Email: holger.goerg@ifw-kiel.de

www.ifw-kiel.de
Yama Temouri

Aston Business School, Aston

University

Birmingham, B4 7ET

United Kingdom.

Email:y.temouri1@aston.ac.uk

www.aston.ac.uk/aston-business-

school

* Holger Görg gratefully acknowledges financial support from the NORFACE ERA-NET (New Opportunities for Research Funding Agency Co-operation in Europe Network) Welfare State Futures Programme, Grant Number 462-14-120 and from the Leibniz Association through the "Kiel Centre for Globalization". 


\section{INTODUCTION}

Discussions on the effects of firm flexibility remain -in spite of the vast literature on the topicprominent, both in the academic literature and among policy makers. One factor that affects firm flexibility that has been discussed recently is the institutional environment, and more specifically, labour market regulations. Employment protection legislation (EPL) in particular is seen as an important source of firm inflexibility as it causes firms to incur adjustment costs in the form of redundancy payments whenever workers are laid off. ${ }^{1}$

It is therefore not surprising that there is a sizeable body of work studying the effect of EPL on a firm's decision to enter a market. This is particularly relevant for multinational enterprises (MNEs), which consider multiple host countries as potential production locations. The empirical evidence provided by the literature (using aggregate country level data) generally shows that EPL acts as a barrier to entry for international firms considering foreign direct investment (FDI) in potential host countries. ${ }^{2}$ The advantage offered by flexible labour markets is clear: they allow MNEs to hire and fire easily, thus enabling them to adjust production easily to changes in economic conditions.

What has been largely neglected in this literature is the fact that MNEs may not only care about the state of labour market regulations in the prospective future host market, but also in the country of its current location. In this paper, we study the extent to which EPL is a barrier to exit. $^{3}$ Although EPL as an institutional barrier to exit from a given location has received scant attention in the literature, ${ }^{4}$ it matters in the real world for both firms and governments. If firms considering relocation are hindered in that decision by significant EPL-induced exit costs, their internationalisation strategy may be inhibited, preventing them from reaping the possible gains

\footnotetext{
${ }^{1}$ When EPL is high, it is costly to fire workers and hence employment responses to shocks and/or the business cycle are smaller (see, for instance, Bertola and Rogerson, 1997; Garibaldi, 1998; Messina and Vallanti, 2007). Also, EPL gives firms an incentive to limit changes in output (see, for instance, Bertola et al., 2010). Belot et al. (2007) show that EPL effects on welfare are non-monotonic.

2 MNEs tend to prefer locations with low levels of labour market regulation (Javorcik and Spatareanu, 2005; Olney, 2013). Work examining the link between employment protection legislation and FDI presents evidence of the negative effect of EPL on inward FDI (e.g., Nicoletti et al, 2003, and Görg, 2005). Examples of theoretical work that features the effect of EPL on the location decision of firms are given by Haaland et al. (2003), who discuss this issue for a monopolist firm, and Dewit et al. (2013), who focus on the interaction of firms' location decisions in an oligopolistic framework. Comprehensive reviews of the literature on the general determinants of FDI and multinational production are provided by Barba-Navaretti and Venables (2004) and Blonigen (2005).

${ }^{3}$ In the spirit of Stigler's (1968) definition of entry barriers, Geroski et al. (1990) define an exit barrier as a cost that a firm must bear in order to leave a market (not borne by firms that are not yet established in the market or by established firms that have not chosen to leave the market).

${ }^{4}$ The literature does, however, offer several examples of government policies that have contributed to or have tried to prevent relocation by firms. For instance, Motta and Thisse (1994) investigate whether a strict environmental policy may cause firms to relocate, and Midelfart-Knarvik et al. (2002) examine how the EU's structural funds affect firm and industry relocation. ${ }^{5}$ For example, Muendler and Becker (2010) and Harrison and McMillan (2011) show that MNEs' relocation of activity can, ceteris paribus, have negative effects on employment in the home country, while Hijzen et al. (2011) find evidence of positive effects. There are numerous extensive reports on relocation (see, for instance, the report commissioned by the European Parliament on the re-localisation of EU industry (2007) and the book by Bhagwati and Blinder (2009) discussing offshoring of American jobs).
} 
from such internationalisation. At the same time, less or slower relocation resulting from strict EPL implies a lower burden in terms of the social adjustment cost potentially accompanying firm relocation. This is especially relevant in an era in which MNEs have become increasingly footloose, leaving some countries with a rapidly eroding industrial base. In fact, the debate on relocation remains intense on either side of the Atlantic, both among academics and policy makers. $^{5}$

We are not only interested in the link between EPL and relocation at the aggregate level but consider differences across firms. We study whether and, if so, to what extent certain firms, due to their specific characteristics, face a higher EPL-induced barrier to exit than other firms. Although EPL is de jure not industry specific, there is good reason to believe that industries are de facto not equally affected by a country's EPL. In fact, it is unlikely that even firms in the same industry will be affected equally. Thus, firm size, productivity and technological differences may imply that different firmsoperating in the same industry effectively face a differential barrier to exit induced by the same country-specific degree of EPL.

The starting points of our analysis are two stylised facts. First, relocation has been particularly relevant in manufacturing ${ }^{6}$ and, second, is mainly motivated by low labour costs abroad, as suggested by survey data (European Commission, 2012). We, therefore, construct a simple and straightforward theoretical framework in which we focus on a firm's relocation decision. We first discuss a benchmark without employment protection and show that firms with different characteristics also differ in their propensity to relocate: a large, highly productive and labour-intensive firm has a higher propensity to relocate than its smaller, less productive and more capital-intensive counterpart. ${ }^{7}$ Second, if there is employment protection in the current production location of the MNE, its propensity to relocate falls due to the EPL-induced exit barrier. We show that this reduction in its propensity to relocate is stronger the larger, more productive or more labour-intensive the firm is. Thus, employment protection creates a larger barrier to exit for those firms that "naturally" have a larger propensity to relocate.

Motivated by the theoretical insights, we conduct an empirical analysis using firm level data in 28 OECD countries for the period 1997-2007. We do this by merging an annual employment protection index with a firm-level dataset to identify firms that reduce their operations at home and at the same time open up new foreign affiliates or acquire existing firms abroad. Our dataset, therefore, allows us to capture not only the home country of the MNE but also the destination country to which the relocation takes place. Our results for firms in manufacturing are broadly in line with the theoretical expectations as outlined above. ${ }^{8}$

\footnotetext{
5 For example, Muendler and Becker (2010) and Harrison and McMillan (2011) show that MNEs' relocation of activity can, ceteris paribus, have negative effects on employment in the home country, while Hijzen et al. (2011) find evidence of positive effects. There are numerous extensive reports on relocation (see, for instance, the report commissioned by the European Parliament on the re-localisation of EU industry (2007) and the book by Bhagwati and Blinder (2009) discussing offshoring of American jobs).

${ }^{6}$ Cohen (2006) and Amiti and Wei (2005) point out that relocation in services is increasing but remains low. Blinder (2007), however, perceives the observed increase in relocation in services more as a threat to jobs in the source country.

7 This is in line with Pennings and Sleuwaegen (2000, 2006), who show -for a dataset of Belgian firms-that firms' propensity to relocate strongly depends on firm-specific characteristics. Other empirical work includes Aw and Lee (2008) and Chen and Moore (2010), who study the location decisions of French and Taiwanese multinationals, respectively. None of these studies look at the effect of EPL in the home country on firms' relocation decisions.

"Note that, in both our theoretical model and the empirical analysis, we are limited to investigating relocation at the "extensive margin". The main reason is that our firm level data does not observe well employment figures and wages for
} 
Our findings have important policy implications. Indeed, firms that relocate are likely to be large and productive and hence their relocation may potentially cause large job losses in the country from where they relocate. However, strict EPL in the latter may render such a large firm relocation scenario less likely by significantly reducing the propensity to relocate for these types of firms. While this means that firms in such countries are restricted in reaping the potential gains from internationalisation, it also means that countries with strict EPL may be less susceptible to massive employment losses induced by large-firm relocation than those with rather lax EPL.

As far as we are aware, there are few studies that study the link between EPL and relocation. Dewit et al. (2009) examine the effect of EPL on aggregate bilateral in- and outward FDI-flows between countries. While Dewit et al. (2009) is concerned with the effect of EPL on aggregate bilateral in- and outward FDI-flows between countries, this paper differs in focus in that it examines how firm-specific features may magnify or indeed mitigate the effects of EPL as a barrier to relocate.

In Section 2, we set up a theoretical framework that models the relocation decision of a firm and discusses how specific firm-characteristics affect that decision. In Section 3, we present an empirical model and describe our data set. Section 4 reports our results and Section 5 concludes.

\section{MODELLING A FIRM'S RELOCATION DECISION}

Aiming to illustrate how an individual firm's specific characteristics affect its relocation decision when it faces employment protection in its initial production location, we set up a stylised framework. Consider a firm that produces for an integrated market for two periods. The firm has some degree of market power and thus faces a downward sloping residual demand function. ${ }^{9}$ Its demand in the integrated market in each period $t$ is given by

$p_{t}=a-q_{t}$

where $p_{t}$ denotes the price and $q_{t}$ stands for output in period $t(t=1,2)$.

There are two possible production locations, countries 'Home' $(H)$ and 'Foreign' $(F)$. We assume that the firm's production location in period one is country $H$ and that the fixed cost of setting up a plant in $H$ has been sunk; hence there are no fixed costs to be incurred in period

\footnotetext{
affiliate firms, particularly in developing countries. Ideally, we would have liked to test for relocation determinants due to shifting employment patterns between existing affiliates, but significant missing information for both employee numbers and wages does not allow us to capture this "intensive margin". However, while having such information may potentially offer an interesting additional channel through which one can document relocation patterns, it would not alter the main qualitative results concerning the extensive margin of relocation obtained in this paper.

${ }^{9}$ The dataset we will use consists of firms from various subsectors in manufacturing, some of which may be best modelled as monopolistically competitive, while others are best captured by an oligopolistic market structure. So, it is unlikely to be the case that one market structure fits all subsectors. However, since we are not concerned with sorting the firms in a particular monopolistically competitive subsector into groups, nor aim to study strategic relocation choices typically present in an oligopolistic setting, we choose to remain agnostic about the market structure in which the firm operates.
} 
one. ${ }^{10}$ The firm uses two factors of production, labour $\left(l_{t}\right)$ and capital $\left(k_{t}\right)$. Factor prices for labour and capital in Home are the same in both periods and are respectively denoted by the wage, $w^{H}$, and the rental rate, $r^{H}$. Factor prices in 'Foreign' are $w^{F}$ and $r^{F}$ for labour and capital respectively. While the factor price of capital, $r^{F}$, remains constant over the two periods, the firm faces uncertainty about the wage in Foreign in period two. More specifically, there is a possibility that an exogenous idiosyncratic wage shock will occur in Foreign in period two. Let $\rho$ denote the probability that the wage rate in Foreign is equal to the Foreign period-one wage (i.e., $w_{2}^{F}=w_{1}^{F}$ ). With the complementary probability, $1-\rho$, Foreign's period-2 wage rate is given by $w_{2}^{F}=w_{1}^{F}-z$ (with $z>0$ ). We assume that, after such a wage shock has occurred, labour in $F$ is relatively cheap, i.e., $w_{2}^{F} / r^{F}<w^{H} / r^{H}$. When uncertainty is resolved in period two and the firm observes the actual wage in Foreign, the firm chooses either to stay in country $H$ or to relocate to country $F .{ }^{11}$ Its costs depend on the production location. If it decides to produce in $F$ in period two, it will incur a fixed cost of setting up a plant there, denoted by $\Phi^{F}$.

While local factor prices are exogenously given to the firm, unit factor requirements for labour and capital, denoted by $\alpha_{l}$ and $\alpha_{k}$, are assumed to be identical across countries but different across firms; their reciprocals represent the marginal productivity of labour and capital within the firm. Marginal production costs for period $t$ in country $F, c_{t}^{F}$, are given by:

$c_{t}^{F}=\alpha_{l} w_{t}^{F}+\alpha_{k} r^{F}$

while marginal production costs in country $H$ in both periods are given by: ${ }^{12}$

$c^{H}=\alpha_{l} w^{H}+\alpha_{k} r^{H}$

The firm's workforce in period $t$ is $l_{t}=\alpha_{l} q_{t}$, whereas its capital is $k_{t}=\alpha_{k} q_{t}$, implying that its labour-capital rate is equal to $\alpha_{l} / \alpha_{k}$. Note that, since unit factor requirements, $\alpha_{l}$ and $\alpha_{k}$, are firm-specific, $c^{H}$ and $c_{2}^{F}$ are too.

Apart from production costs, the firm incurs potential firing costs. More specifically, in country $H$, there is employment protection regulation. As a result, firms producing in $H$ incur firing costs if they reduce the number of workers. Firing costs are represented by $I \lambda^{H} \alpha_{l}\left(q_{1}^{H}-q_{2}^{H}\right)$, where $\lambda^{H}$ is a parameter that captures the degree of EPL (with higher values

\footnotetext{
${ }^{10}$ The firm could either be a domestic firm of country H or a multinational that previously decided to locate there. We do not focus on the firm's initial location decision here as it does not feature in the empirical part of the paper. Naturally, when initially setting up a plant in Home, firms would have taken local EPL into account. This would affect a firm's initial size as it would take into account that future relocation is a possibility. For an explicit investigation of the effect of EPL on firms' initial location decisions, see Dewit et al. (2009).

${ }^{11}$ Note that other types of shocks, such as an increase in period two in the Home wage rate, or even a positive demand shock in the integrated market in period two, can give the firm a similar incentive to relocate. For instance, Dewit et al. (2009) model relocation as a result of a permanent positive demand shock.

12 The cost specification is based on a Leontief production technology. This assumption is imposed for simplicity, but does not affect the results of the model in a qualitative sense. A more flexible production technology would imply that the incentive to relocate would be higher (as firms would substitute capital for labour as the latter is relatively cheaper in Foreign), but would not affect the EPL-induced exit costs from the Home location.
} 
reflecting stricter EPL); $I$ is an indicator variable with $I=1$ if $q_{1}^{H}>q_{2}^{H}$ and $I=0$ otherwise. By contrast, there is no EPL in country $F$ (i.e., $\left.\lambda^{F}=0\right) .{ }^{13}$

Let us now describe the firm's decisions. In period one, the firm, located in country $H$, chooses its output level for that period, while facing uncertainty about the period-two wage rate in Foreign. At the start of period two, the period-two Foreign wage is observed and the firm decides whether or not to relocate to region $F$. It also chooses its period-two output level. There are two possible dynamic location equilibria. Using $H_{t}$ and $F_{t}$, respectively, to denote Home and Foreign as the chosen production location in time period $t$, we have $\left(H_{1}, H_{2}\right)$, the equilibrium in which the firm stays in the initial production location, and $\left(H_{1}, F_{2}\right)$, the equilibrium in which the firm relocates to the region without employment protection. Naturally, in practice, the equilibrium without relocation will occur most of the time since the firm would not have chosen $H$ as its initial location otherwise. However, since we want to analyse the possible relocation decision of a firm facing employment protection, we will focus on when the relocation equilibrium $\left(H_{1}, F_{2}\right)$ is likely to occur.

In period two, the firm relocates if period-two profits from relocation, $\pi_{2}\left(H_{1}, F_{2}\right)$, exceed period-two profits from staying in country $H, \pi_{2}\left(H_{1}, H_{2}\right)$. So, the firm's relocation condition is:

$\pi_{2}\left(H_{1}, F_{2}\right)>\pi_{2}\left(H_{1}, H_{2}\right)$.

If the firm relocates to $F$, it shuts down its plant in $H$, thus incurring EPL-induced exit costs, $\lambda^{H} \alpha_{l} q_{1}^{H} .^{14}$ In addition, the set-up costs of the new plant in country $F$ have to be paid. Hence, period-two profits in case of relocation are:

$\pi_{2}\left(H_{1}, F_{2}\right)=\left(p_{2}-c_{2}^{F}\right) q_{2}^{F}-\lambda^{H} \alpha_{l} q_{1}^{H}-\Phi^{F}$

If, however, the firm decides to stay in $H$ in period two, it occurs firing costs only if and to the extent that period-two output is lower than its period-one output level; its profit function is:

$$
\pi_{2}\left(H_{1}, H_{2}\right)=\left(p_{2}-c^{H}\right) q_{2}^{H}-I \lambda^{H} \alpha_{l}\left(q_{1}^{H}-q_{2}^{H}\right)
$$

A comparison of expressions (4a) and (4b) shows that $c_{2}^{F}<c^{H}$ is a necessary -but not sufficient- condition for relocation (i.e., for expression (3) to hold). Using the expressions for optimal output levels (which are derived in Appendix A), we can rewrite the relocation condition (expression (3)) as:

\footnotetext{
${ }^{13}$ It is straightforward to incorporate EPL in Foreign, with $\lambda^{H}>\lambda^{F}$. This would not change anything in our two-period model. In a more dynamic extension of the model, in which another period would be added, it may raise the barrier to entry into Foreign and therefore reduce the relative attractiveness of that location. As a result, the firm's propensity to relocate to Foreign would fall, but the qualitative relationship between the firm's EPL-induced exit cost from Home and that firm's propensity to relocate to Foreign would remain unaltered.

${ }^{14}$ For simplicity, we abstract from partial relocation in this stylised set-up. Partial relocation would be obtained if, for instance, the production process exhibited increasing marginal costs. Of course, real-world relocation is typically partial, which is how we define relocation in the empirical model. However, partial relocation does not alter the qualitative relationship between relocation and employment protection and hence the sign predictions obtained from our theoretical framework are applicable to partial as well as complete relocation.
} 
$\frac{\left(a-c_{2}^{F}\right)^{2}-\left(a-c^{H}\right)^{2}}{4}>\Phi^{F}+\lambda^{H} \alpha_{l} q_{1}^{H}$

So, with $c^{H}>c_{2}^{F}$, relocation is possible and, ceteris paribus, more likely if the wage shock in Foreign $(z)$ is large since it widens the difference between prospective operating profits in $F$ and $H$ (that is, the left-hand-side of the inequality in (5) increases). If there were no EPL in $H$ $\left(\lambda^{H}=0\right)$, the firm would relocate to country $F$ provided that the gap in operating profits between $F$ and $H$ is wide enough to compensate for the entry costs $\left(\Phi^{F}\right)$ associated with relocation. However, given the EPL in country $H\left(\lambda^{H}>0\right)$, a firm that considers relocating faces firing costs and hence exit costs from country $H$ (captured by the second term of the right-handside of the inequality in (5)). So, relative to the case in which there is no EPL in $H$, the gap in operating profits between $F$ and $H$ now needs to be wider for the firm to relocate to country $F$ in order to compensate for the additional exit costs associated with relocation.

We now provide an intuitive interpretation of the relocation condition for firms that are facing EPL in their initial production location, focussing on three firm-specific features: size, productivity and labour intensity.

First, we examine how firm size affects a firm's propensity to relocate. In the absence of EPL, larger firms have a higher propensity to relocate. The period-two cost advantage when producing in $F$ applies to a larger volume of production when the firm is larger, which magnifies the profit difference between producing in $F$ or in $H$ more than for a small firm. A similar reasoning pertains to lower-cost (i.e., more productive) firms. All else equal, lower-cost firms will produce more than their higher-cost counterparts. Presented with a period-two cost advantage when producing in $F$ thus also widens the operating profits between producing in $H$ and in $F$ more than for a similar higher-cost (less productive) firm. So, just like larger firms have greater potential gains from relocating to $F$ than smaller ones, more productive firms gain more from relocating than less productive ones. ${ }^{15}$ However, all else equal, EPL-induced exit costs are also higher for larger and more productive firms simply because their initial output level in $H$, and hence their firing cost when relocating, are higher. This implies that, ceteris paribus, larger and more productive firms have higher exit costs from a country with high EPL than their smaller and less productive counterparts, which mitigate their relatively higher potential gains from relocation. It suggests that EPL tends to narrow the differences in the propensity to relocate between large and small firms and between more and less productive ones.

Next, we take a closer look at the effect of labour intensity on a firm's propensity to relocate. To isolate the labour intensity from the firm productivity effect, we compare the propensity to relocate for home firms that are equally productive, or, have the same marginal production costs $\left(c^{H}\right)$, but operate with different relative labour intensities. In the absence of EPL, the gain of relocation towards countries in which labour is relatively cheap is naturally higher for more labour intensive firms. However, EPL in the country from where the firm considers relocation raises exit costs $\left(\lambda^{H} \alpha_{l} q_{1}^{H}\right)$ and these exit costs are higher the more labour intensive the firm is (i.e., the higher $\alpha_{l}$ ). So, among equally productive, equally-sized firms, we

\footnotetext{
${ }^{15}$ This is consistent with the result found in Helpman et al. (2004) that only the most productive firms engage in FDI as only they make sufficient operating profit to cover the set-up cost of FDI.
} 
expect that highly labour-intensive firms gain most from relocation, while these are at the same time being hindered most in their relocation decision if they face high levels of EPL in the country from which they consider relocation. Thus, we expect that the difference in relocation propensity between firms with a high and a low labour intensity will be narrowed by EPL and will decrease as the degree of EPL becomes stricter.

\section{EMPIRICAL EVIDENCE}

\section{Empirical Model}

The above discussion of the theoretical model provides the motivation for a number of hypotheses which we investigate in the remainder of the paper:

1. The level of employment protection in the home country is negatively associated with the relocation decision of the firms that produce there.

While this is, per se, not surprising, taking into account firm-specific features provides a more complex set of hypotheses:

2. Firm size, productivity and labour intensity affect a firm's propensity to relocate positively.

3. Employment protection lowers the propensity to relocate for large firms more than for small firms, for highly productive firms more than for less productive firms, and more for firms with a high labour intensity than for those with a low labour intensity.

In order to check the empirical validity or otherwise of these theoretically derived hypotheses, we propose to estimate the propensity to relocate for firm $i, \operatorname{Pr}(D)_{i t}$, conditional on a set of covariates. Specifically, we estimate:

$$
\operatorname{Pr}(D)_{i t}=\beta_{1} \lambda_{h t}+\beta_{2} C_{i t}+\beta_{3}\left(\lambda_{h t} * C_{i t}\right)+\beta_{4} X_{i t}+\varepsilon i t
$$

where $\lambda_{h t}$ is the level of employment protection in firm $i^{\prime}$ s home country $h$ at time $t$. $C_{i t}$ is, alternatively, the size, productivity or labour intensity of firm $i$ at time $t$ and $X_{i t}$ is a vector of control variables. The model also includes full sets of industry, year and country dummies. Hypotheses 1 to 3 imply $\beta_{1}<0, \beta_{2}>0$ and $\beta_{3}<0$.

\section{Data description}

The empirical model described in (6) is estimated using firm level data on the location decisions of firms from 28 OECD home countries. Our data covers the manufacturing sector, as the theoretical background framework was set up with the manufacturing sector in mind, for which low foreign wages have been highlighted as one of the main reasons for relocation in the sector.

The dataset is collected from ORBIS, which is a comprehensive and rich firm-level dataset provided by Bureau van Dijk. Bureau van Dijk collects financial, economic and other firm-level information from various sources, including official bodies such as Companies House in the UK and similar commercial and official registries in other countries. Our sample includes an unbalanced panel of firms in 28 OECD countries for the period 1997-2007. We have information on the characteristics of the firms, such as location, output, employment, labour intensity, 
productivity, industry classification on an annual basis, and we can crucially observe whether they have reduced their operations at home and at the same time set up affiliates abroad. ${ }^{16}$

We define "relocation" in our empirical analysis in three ways. Our first definition is similar to Pennings and Sleuwaegen (2000), who define relocation as a firm reducing its operations at home by more than 10 per cent of their size (measured in number of employees) and at the same time opening up a new foreign affiliate or acquire an existing firm abroad. We will refer to this relocation definition as "Definition 1". The establishment of the foreign affiliate is based on the date of incorporation of the foreign affiliate which is also available in the data set. Our second definition of relocation -henceforth referred to as "Definition 2"- is more flexible in terms of the timing of the relocation, such that we allow for a one year window before and after the establishment of the affiliate abroad. MNEs may decide to reduce employment before or after the decision of relocation is taken. Our third definition -"Definition 3"- tests the sensitivity of the 10 per cent employment reduction in the labour force at home and adopts a common criterion for mass layoffs used in the labour economics literature of 30 per cent (Jacobson, 1993). Definitions 2 and 3 will act as robustness checks for our baseline results.

Since a firm may have more than one foreign affiliate, and therefore qualifies potentially as having carried out more than one relocation, we construct the dataset in bilateral form. Our dataset includes 28 OECD countries (where the parent firm is located) and 95 different host countries (where foreign affiliates are located). Each parent firm has at least one foreign affiliate, in which case it appears once in the dataset with that home-host combination. Therefore a parent firm appears as many times as it has affiliates in different host countries. The vast majority of firms have few foreign affiliates. For example, 60 per cent of the firms have 5 foreign affiliates or less in different host countries. The average number of host countries that a parent firm has a foreign affiliate in is 7.5 (range is 1-59 host countries). ${ }^{17}$

We use two-digit primary NACE industry codes to classify firms in the manufacturing sector (i.e. NACE 15-37). Since our analysis is based on registered firms and their filed accounts, all large firms as well as a significant share of small and medium sized firms are included in the database, which provides a good coverage across OECD countries. ${ }^{18}$

Annual data on employment protection are obtained from the World Competitiveness Report of the World Economic Forum. ${ }^{19}$ This is an index that is constructed from extensive surveys of managers in 138 countries, conducted by the World Economic Forum. In the survey, participants are asked to give a score to a number of questions describing the overall business climate and competitiveness of the country in which the firm operates. The scale of this index for the period 1997-2007 ranges from 1 to 7 . The particular criterion for the index used here is: "Hiring and firing practices are too restricted by the government or are flexible enough". The index is

\footnotetext{
${ }^{16}$ A firm owns a foreign affiliate if it holds at least 10 percent of the voting stocks. ORBIS reports firm accounts in either consolidated or unconsolidated form. We include only unconsolidated accounts as they represent the domestic activities of firms and exclude any information from affiliates at home or abroad. In contrast, consolidated accounts aggregate the activities of all firms belonging to a group worldwide, regardless of location and industrial affiliation.

17 In cases where firms have more than one affiliate in the same host country, they are treated the same as firms that are in the host country with one affiliate. This should not pose a problem for the purposes of this paper.

${ }^{18}$ Desai et al. (2003) discuss data collection by Bureau van Dijk and conclude that, across countries, the database represents economies quite well. Klapper et al. (2004) also point to its large coverage compared to other data sources.

${ }^{19}$ Similar data were used by Di Tella and MacCulloch (2005) and Amiti and Wakelin (2003).
} 
defined in such a way that a higher value reflects a more protected labour environment. In other words, $\lambda^{H}$ is scaled such that a higher index refers to a higher degree of employment protection. Hence, a negative sign of the relevant coefficient will indicate that higher labour protection hinders relocation $\left(\beta_{1}<0\right)$, as expected from the theoretical discussion.

We measure a firm's size by its number of employees. Labour intensity is measured by the ratio of labour to capital. We measure productivity by estimating total factor productivity using the now common method by Levinsohn and Petrin (2003), which controls for simultaneity in input choice. Other firm level controls that may be correlated with the propensity to relocate are a firm's average wage level and the ratio of intangible to total assets. Lower wages abroad increase the likelihood for firms to consider relocation options there (as suggested by a fall in $w_{2}^{F}$ in the theoretical framework). Intangible to total assets are used as an (imperfect) indicator of firm-specific assets (Markusen, 1995), with higher levels of intangible to total assets increasing a firm's likelihood of moving abroad via relocation, in order to reap the benefits of its firm specific advantages.

As each OECD member country has its own institutional environment in which firms operate, we control for some of the time varying country-level differences by including the corporate tax rate in the home country, as one of the main macroeconomic variables determining firm location and relocation (De Mooij and Ederveen, 2003). We expect that the higher the tax rate in the home country, the higher the likelihood of firms to move abroad.

Finally, since we not only know the home country of the investor but also the destination country to which the relocation takes place, we include in the empirical specification host country - time dummies to control for time varying unobserved destination specific effects. The definition and sources of all variables included in the model is provided in Appendix B.

To address potential endogeneity between a firm's relocation in a given year and our variables measuring firm characteristics such as labour intensity, we have lagged all our right hand side variables by one period. We are aware that this is not optimal but in the absence of convincing instruments for the firm characteristics, we proceed in this way and are careful not to over-interpret our results on firm characteristics as causal effects. The main variable of interest, EPL is measured at the country level and is therefore less likely to be endogenous to a firm's decision to relocate.

We utilise two estimators, namely a pooled probit and a random effects panel probit estimator. To control for potential path dependence, we include a lag of the dependent variable for both estimators. We also utilise Wooldridge (2005) to address the initial condition problem and delivering consistent estimates. Hence, this approach deals with firm unobserved heterogeneity that is intrinsic to firms from the initial period of observation, which may induce endogeneity concerns in the model. In order to minimise spurious correlation between the decision to relocate and other non-observables, we also control for country, industry and year fixed effects, by including full sets of dummies at these levels.

Table 1 shows the coverage of OECD firms that either relocate or not, at some point during our sample period 1997-2007. The majority of relocating firms are based in Europe and North America with significant numbers from Eastern Europe as well as Japan and South Korea. These multinational firms invest heavily in other developed or OECD countries; around 30 per cent of affiliates are located outside the OECD. 


\begin{tabular}{|c|c|c|c|c|}
\hline & $\begin{array}{c}\text { Employment } \\
\text { protection index } \\
\text { (Average) }\end{array}$ & $\begin{array}{l}\text { Employment } \\
\text { protection Index } \\
(\mathrm{sd})\end{array}$ & $\begin{array}{c}\text { Number of firms } \\
\text { not relocating }\end{array}$ & $\begin{array}{c}\text { Number of Firms } \\
\text { that relocate }\end{array}$ \\
\hline Austria & 3.69 & 0.37 & 466 & 62 \\
\hline Australia & 3.61 & 0.35 & 39 & 1 \\
\hline Belgium & 4.37 & 0.41 & 671 & 130 \\
\hline Canada & 2.59 & 0.25 & 466 & 11 \\
\hline Switzerland & 1.74 & 0.47 & 908 & 109 \\
\hline Czech Republic & 3.22 & 0.67 & 193 & 49 \\
\hline Germany & 4.78 & 0.24 & 1,808 & 151 \\
\hline Denmark & 1.67 & 0.46 & 288 & 33 \\
\hline Estonia & 2.74 & 0.32 & 32 & 12 \\
\hline Spain & 4.14 & 0.34 & 1,276 & 178 \\
\hline Finland & 3.58 & 0.38 & 234 & 82 \\
\hline France & 4.65 & 0.19 & 1,330 & 164 \\
\hline Great Britain & 2.51 & 0.57 & 429 & 94 \\
\hline Greece & 4.24 & 0.17 & 27 & 1 \\
\hline Hungary & 2.69 & 0.69 & 30 & 1 \\
\hline Ireland & 3.58 & 0.37 & 50 & 3 \\
\hline Italy & 4.57 & 0.21 & 2,118 & 526 \\
\hline Japan & 3.45 & 0.56 & 360 & 62 \\
\hline Korea & 3.24 & 0.43 & 44 & 10 \\
\hline Luxembourg & 3.75 & 0.48 & 12 & 1 \\
\hline Mexico & 3.52 & 0.40 & 42 & 5 \\
\hline Norway & 4.41 & 0.22 & 184 & 36 \\
\hline Poland & 3.40 & 0.42 & 68 & 4 \\
\hline Portugal & 4.23 & 0.21 & 149 & 12 \\
\hline Sweden & 4.57 & 0.30 & 592 & 152 \\
\hline Slovenia & 4.31 & 0.19 & 74 & 21 \\
\hline Slovakia & 2.95 & 0.67 & 93 & 20 \\
\hline United States & 1.86 & 0.23 & 987 & 19 \\
\hline Non-OECD countries ${ }^{*}$ & & & -- & -- \\
\hline Total & & & 12,970 & 1,949 \\
\hline
\end{tabular}

Source: Authors calculations using ORBIS. The countries in the Non-OECD group include: UAE, Albania, Armenia, Angola, Argentina, Azerbaijan, Bosnia and Herzegovina, Barbados, Bangladesh, Burkina Faso, Bulgaria, Bahrain, Burundi, Benin, Bolivia, Brazil, Botswana, Cameroon, China, Colombia, Costa Rica, Cyprus, Dominican Republic, Algeria, Ecuador, Egypt, Ethiopia, Georgia, Ghana, Guatemala, Hong Kong, Honduras, Croatia, Indonesia, India, Jamaica, Jordan, Kenya, Cambodia, Kuwait, Kazakhstan, Sri Lanka, Lithuania, Latvia, Libya, Morocco, Moldova, Madagascar, Macedonia, Mali, Mongolia, Mauritania, Malta, Mauritius, Malawi, Malaysia, Mozambique, Namibia, Nigeria, Nicaragua, Oman, Panama, Peru, Philippines, Pakistan, Paraguay, Qatar, Romania, Russia, Saudi Arabia, Singapore, Senegal, Suriname, El Salvador, Syria, Chad, Thailand, Tunisia, Trinidad and Tobago, Taiwan, Tanzania, Ukraine, Uganda, Uruguay, Uzbekistan, Venezuela, Vietnam, South Africa, Zambia, Zimbabwe.

Since relocation is quite a drastic decision, it is not surprising that firms that actually relocate make up a small proportion of all firms. In other words, column three shows that the number of firms that do not relocate within the period 1997-2007 is much higher than the number of firms that relocate in almost every OECD country (i.e. column 4). The employment protection index also varies significantly across countries as well as across years during our sample period.

Table 2 presents summary statistics for the key variables that characterise relocating firms and firms which do not relocate, for the high-tech and low-tech manufacturing sectors separately (see Appendix Table B1 for the classification). Distinguishing relocating from non-relocating 
firms shows that, in manufacturing, we find that the former are "better" in terms of most aspects of firm characteristics measured, namely larger and more productive, and less labour intensive.

\begin{tabular}{lcc}
\hline Table 2: Summary Statistics of firm-level variables & & \\
\hline \multicolumn{1}{c}{ Variable (definition) } & Relocating Firms & Non - Relocating Firms \\
& $\begin{array}{c}\text { Mean } \\
\text { (sd) }\end{array}$ & $\begin{array}{c}\text { Mean } \\
\text { (sd) }\end{array}$ \\
& & \\
& 1,114 & 533 \\
High-tech Manufacturing sector & $(3,033)$ & $(3,124)$ \\
Number of employees & -3.88 & -3.35 \\
& $(1.76)$ & $(1.35)$ \\
Log Labour-intensity & 5.18 & 4.82 \\
& $(0.80)$ & $(0.62)$ \\
Log TFP & & \\
& 677 & 392 \\
Low-tech Manufacturing sector & $(1,867)$ & $(2,556)$ \\
\hline Number of employees & -4.25 & -3.67 \\
& $(1.80)$ & $(1.29)$ \\
Log Labour-intensity & 4.92 & 4.72 \\
& $(0.81)$ & $(0.60)$ \\
\hline
\end{tabular}

Source: Authors' calculations using ORBIS database.

\section{Estimation results}

The baseline estimation results from the probit and random effects panel probit regressions of equation (6) without the vector $X$ are presented in Tables 3a-3c for each of the relocation definitions. Overall, we find broad empirical support for hypotheses 1 to 3 stated above.

We start with a specification including only EPL without interactions in Table 3a, column (1). This shows, as expected, that higher employment protection in the home country discourages firms' relocation activity. While the direction of this effect is clear, it is difficult to gauge the economic importance of the estimated effect. In order to say something more about the actual meaning of the estimated relationship, we use the model to calculate predicted values of relocating for two hypothetical economies. We set all control variables to their mean levels but let the level of home country EPL differ, setting it in one case equal to 2.59 (the level of Canada) and the other case to 4.65 (the level of France). Our model predicts that, in the first case, we have a relocation probability of 6.6 percent, in the second case of 2.0 percent. This implies that, for an economy at mean levels of covariates, if we increase the level of employment protection from the relatively low level of Canada to the higher level of France, we would reduce the relocation probability of the average firm by 4.6 percentage points. This is an economically significant effect. ${ }^{20}$

In columns (2) and (6) we consider the role of firm size for the link between employment protection and relocation. We find that larger firms are more likely to relocate activity. As suggested by our theoretical model, the negative coefficient on the interaction of size and Home employment protection indicates that employment protection lowers the propensity to relocate

\footnotetext{
20 These estimations are carried out using the "margins" command in Stata.
} 


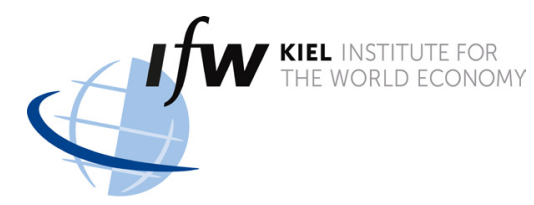

more for firms that are large. ${ }^{21}$ In fact, irrespective of whether Definition 1, 2 or 3 is used for relocation, we find similar results with respect to Home employment protection, firm size and their interaction term.

In the further specifications in Tables $3 a-3 c$ we consider the impact of the other firm characteristics included in our theoretical model, namely labour intensity and productivity, respectively. We find, in line with our expectation, that while more labour intensive firms are more likely to relocate, their propensity to relocate is significantly more mitigated by employment protection than their less labour intensive counterparts' relocation propensity. Again, these results hold for all three definitions of relocation.

Our results for the relationship between productivity and relocation are, however, less clear cut when different definitions for relocation are used. Using Definition 2 of relocation (see Table 3b), our estimations seem to indicate that more productive firms are less likely to ("massively") relocate and are less likely to be hindered by Home employment protection in relocating than their less productive counterparts. But, this effect seems to be somewhat weaker when considering Definitions 1 and 3 (see Tables 3a and 3c). As will be discussed, we find that this is driven by low-tech manufacturing industries and that the results for the high-tech manufacturing sector are as expected (see Tables 5 and 6 ).

\footnotetext{
${ }^{21}$ Calculation of marginal effects indicates that increasing the value of the interaction term from the $10^{\text {th }}$ percentile to the median value - while keeping all other covariates constant at their mean - reduces the probability to relocate by 1.4 percentage points.
} 
Table 3a: Baseline results - Definition 1 of Relocation (i.e. instant)

\begin{tabular}{|c|c|c|c|c|c|c|c|c|}
\hline & \multicolumn{4}{|c|}{ Probit Model (Marginal effects) } & \multicolumn{4}{|c|}{ Random Effects Panel Probit Model } \\
\hline & 1 & 2 & 3 & 4 & 5 & 6 & 7 & 8 \\
\hline \multirow{2}{*}{ Relocation $(\mathrm{t}-1)$} & $0.147^{* * *}$ & $0.149 * * *$ & $0.157^{* * *}$ & $0.155^{* * *}$ & $0.224 * * *$ & $0.216 * * *$ & $0.249 * * *$ & $0.279 * * *$ \\
\hline & $(0.008)$ & $(0.008)$ & $(0.012)$ & $(0.013)$ & $(0.0409)$ & $(0.0409)$ & $(0.0422)$ & $(0.0447)$ \\
\hline \multirow[t]{2}{*}{ Home $\lambda$} & $-0.018 * * *$ & $-0.013 * * *$ & $-0.032 * * *$ & $-0.024 * * *$ & $-0.285^{* * *}$ & $-0.198 * * *$ & $-0.530 * * *$ & $-0.394 * * *$ \\
\hline & $(0.00214)$ & $(0.003)$ & $(0.006)$ & $(0.004)$ & $(0.0362)$ & $(0.0529)$ & $(0.0584)$ & $(0.0422)$ \\
\hline \multirow[t]{2}{*}{ Size } & & $0.005 * * *$ & & & & $0.111^{* * *}$ & & \\
\hline & & $(0.002)$ & & & & $(0.0289)$ & & \\
\hline \multirow[t]{2}{*}{ Size $*$ Home $\lambda$} & & $-0.001 * *$ & & & & $-0.0157^{* *}$ & & \\
\hline & & $(0.0003)$ & & & & $(0.00688)$ & & \\
\hline \multirow[t]{2}{*}{ Labour intensity } & & & $0.013 * * *$ & & & & $0.266^{* * *}$ & \\
\hline & & & $(0.005)$ & & & & $(0.0487)$ & \\
\hline \multirow[t]{2}{*}{ Labour intensity $*$ Home $\lambda$} & & & $-0.002 * *$ & & & & $-0.0483 * * *$ & \\
\hline & & & $(0.001)$ & & & & $(0.0114)$ & \\
\hline \multirow[t]{2}{*}{ TFP } & & & & $-6.73 e-05$ & & & & $-0.00130 * * *$ \\
\hline & & & & $(4.23 e-05)$ & & & & $(0.000445)$ \\
\hline \multirow[t]{2}{*}{ TFP $*$ Home $\lambda$} & & & & $1.51 \mathrm{e}-05^{*}$ & & & & $0.000287 * * *$ \\
\hline & & & & (8.96e-06) & & & & $(9.54 \mathrm{e}-05)$ \\
\hline Predicted probability & 0.038 & 0.038 & 0.035 & 0.039 & & & & \\
\hline Wald chi2 & 2367.590 & 2372.140 & 1051.260 & 968.17 & 1002.79 & & & \\
\hline Prob > chi2 & 0.000 & 0.000 & 0.000 & 0.000 & 0.0000 & & & \\
\hline Pseudo R2 & 0.069 & 0.069 & 0.072 & 0.076 & & & & \\
\hline Log pseudolikelihood & $-15,279.767$ & $-15,268.499$ & $-13,819.805$ & $-12,650.074$ & $-14,909.192$ & & & \\
\hline Year, dummies & Yes & Yes & Yes & Yes & Yes & Yes & Yes & Yes \\
\hline Industry dummies & Yes & Yes & Yes & Yes & Yes & Yes & Yes & Yes \\
\hline Country dummies & Yes & Yes & Yes & Yes & Yes & Yes & Yes & Yes \\
\hline Observations & 101,003 & 101,003 & 89,067 & 82,871 & 101,079 & 101,079 & 89,140 & 82,934 \\
\hline
\end{tabular}

Notes: All explanatory variables are lagged one period. All specifications include a full set of year, industry and country dummies and destinations - year pair fixed effects. Clustered standard errors are shown in parenthesis and at the parent country level for the specifications without interactions and at the parent firm-level for the other specifications. ${ }^{* * *} p<0.01$, $* * p<0.05, * p<0.1$ 
Table 3b: Baseline results -Definition 2 of Relocation (i.e. flexible timing)

\begin{tabular}{|c|c|c|c|c|c|c|c|c|}
\hline & \multicolumn{4}{|c|}{ Probit Model (Marginal effects) } & \multicolumn{4}{|c|}{ Random Effects Panel Probit Model } \\
\hline & 1 & 2 & 3 & 4 & 5 & 6 & 7 & 8 \\
\hline Relocation (t-1) & $\begin{array}{c}0.580 * * * \\
(0.004)\end{array}$ & $\begin{array}{c}0.580^{* * *} \\
(0.003)\end{array}$ & $\begin{array}{c}0.581 * * * \\
(0.004)\end{array}$ & $\begin{array}{c}0.581^{* * *} \\
(0.004)\end{array}$ & $\begin{array}{c}1.874 * * * \\
(0.015)\end{array}$ & $\begin{array}{c}1.876^{* * *} \\
(0.015)\end{array}$ & $\begin{array}{c}1.878 * * * \\
(0.016)\end{array}$ & $\begin{array}{c}1.887^{* * *} \\
(0.017)\end{array}$ \\
\hline Home $\lambda$ & $\begin{array}{c}-0.043^{* * *} \\
(0.004)\end{array}$ & $\begin{array}{c}-0.029 * * * \\
(0.005)\end{array}$ & $\begin{array}{c}-0.073^{* * *} \\
(0.007)\end{array}$ & $\begin{array}{c}-0.050^{* * *} \\
(0.000)\end{array}$ & $\begin{array}{c}-0.249 * * * \\
(0.023)\end{array}$ & $\begin{array}{c}-0.170^{* * *} \\
(0.030)\end{array}$ & $\begin{array}{c}-0.427^{* * *} \\
(0.035)\end{array}$ & $\begin{array}{c}-0.295^{* * *} \\
(0.028)\end{array}$ \\
\hline Size & & $\begin{array}{c}0.016 * * * \\
(0.003)\end{array}$ & & & & $\begin{array}{c}0.096 * * * \\
(0.015)\end{array}$ & & \\
\hline Size $*$ Home $\lambda$ & & $\begin{array}{c}-0.002^{* * * *} \\
(0.001)\end{array}$ & & & & $\begin{array}{c}-0.015^{* * *} \\
(0.004)\end{array}$ & & \\
\hline Labour intensity & & & $\begin{array}{c}0.028 * * * \\
(0.005)\end{array}$ & & & & $\begin{array}{c}0.161 * * * \\
(0.027)\end{array}$ & \\
\hline Labour intensity * Home $\lambda$ & & & $\begin{array}{c}-0.007^{* * *} \\
(0.001)\end{array}$ & & & & $\begin{array}{c}-0.040 * * * \\
(0.006)\end{array}$ & \\
\hline TFP & & & & $\begin{array}{c}-8.92 \mathrm{e}-05 \\
(5.7 \mathrm{e}-05)\end{array}$ & & & & $\begin{array}{c}-0.001^{*} \\
(0.000)\end{array}$ \\
\hline TFP $*$ Home $\lambda$ & & & & $\begin{array}{c}2.19 \mathrm{e}-05^{*} \\
(1.25 \mathrm{e}-06)\end{array}$ & & & & $\begin{array}{l}1.3 e-04^{* *} \\
(6.02 e-05)\end{array}$ \\
\hline Predicted probability & 0.096 & 0.096 & 0.097 & 0.095 & & & & \\
\hline Wald chi2 & $32,940.40$ & $32,949.80$ & $29,994.25$ & $27,674.58$ & 18190.24 & 18257.66 & 16769.13 & 15469.55 \\
\hline Prob > chi2 & 0.0000 & 0.000 & 0.000 & 0.000 & 0.0000 & 0.0000 & 0.0000 & 0.0000 \\
\hline Pseudo R2 & 0.261 & 0.262 & 0.270 & 0.272 & & & & \\
\hline Log pseudolikelihood & $-29,653.699$ & -29588.344 & $-26,221.51$ & $-24,089.18$ & $-29,653.70$ & -29588.347 & -26221.511 & -24089.186 \\
\hline Year dummies & Yes & Yes & Yes & Yes & Yes & Yes & Yes & Yes \\
\hline Industry dummies & Yes & Yes & Yes & Yes & Yes & Yes & Yes & Yes \\
\hline Country dummies & Yes & Yes & Yes & Yes & Yes & Yes & Yes & Yes \\
\hline Observations & 101,003 & 101,003 & 89,067 & 82,871 & 101,079 & 101,079 & 89,140 & 82,934 \\
\hline
\end{tabular}

Notes: All explanatory variables are lagged one period. All specifications include a full set of year, industry and country dummies and destinations - year pair fixed effects. Clustered standard errors are shown in parenthesis and at the parent country level for the specifications without interactions and at the parent firm-level for the other specifications. ${ }^{* \star *} p<0.01$, ${ }^{* *} p<0.05,{ }^{*} p<0.1$ 
Table 3c: Baseline results - Definition 3 of Relocation (i.e. mass layoffs)

\begin{tabular}{|c|c|c|c|c|c|c|c|c|}
\hline & \multicolumn{4}{|c|}{ Probit Model (Marginal effects) } & \multicolumn{4}{|c|}{ Random Effects Panel Probit Model } \\
\hline & 1 & 2 & 3 & 4 & 5 & 6 & 7 & 8 \\
\hline Relocation (t-1) & $\begin{array}{c}0.011^{* * *} \\
(0.003)\end{array}$ & $\begin{array}{c}0.014 * * * \\
(0.003)\end{array}$ & $\begin{array}{c}0.008 * * * \\
(0.003)\end{array}$ & $\begin{array}{c}0.003 \\
(0.003)\end{array}$ & $\begin{array}{c}-0.387^{* * *} \\
(0.058)\end{array}$ & $\begin{array}{c}-0.378^{* * *} \\
(0.0585)\end{array}$ & $\begin{array}{c}-0.447^{* * *} \\
(0.0635)\end{array}$ & $\begin{array}{c}-0.508^{* * *} \\
(0.0706)\end{array}$ \\
\hline Home $\lambda$ & $\begin{array}{c}-0.019 * * * \\
(0.002)\end{array}$ & $\begin{array}{c}-0.007^{* * *} \\
(0.003)\end{array}$ & $\begin{array}{c}-0.027^{* * *} \\
(0.003)\end{array}$ & $\begin{array}{c}-0.020^{* * *} \\
(0.002)\end{array}$ & $\begin{array}{c}-0.459 * * * \\
(0.040)\end{array}$ & $\begin{array}{l}-0.106^{*} \\
(0.0608)\end{array}$ & $\begin{array}{c}-0.678^{* * *} \\
(0.0601)\end{array}$ & $\begin{array}{c}-0.506 * * * \\
(0.0454)\end{array}$ \\
\hline Size & & $\begin{array}{c}0.011 * * * \\
(0.001)\end{array}$ & & & & $\begin{array}{r}0.335^{* * *} \\
(0.0335)\end{array}$ & & \\
\hline Size $*$ Home $\lambda$ & & $\begin{array}{c}-0.002^{* * *} \\
(0.000)\end{array}$ & & & & $\begin{array}{c}-0.0611 * * * \\
(0.00785)\end{array}$ & & \\
\hline Labour intensity & & & $\begin{array}{c}0.011^{* * *} \\
(0.002)\end{array}$ & & & & $\begin{array}{r}0.315 * * * \\
(0.0481)\end{array}$ & \\
\hline Labour intensity * Home $\lambda$ & & & $\begin{array}{c}-0.002 * * * \\
(0.001)\end{array}$ & & & & $\begin{array}{c}-0.0592^{* * *} \\
(0.0113)\end{array}$ & \\
\hline TFP & & & & $\begin{array}{c}-7.63 \mathrm{e}-05^{* * *} \\
(1.70 \mathrm{e}-05)\end{array}$ & & & & $\begin{array}{c}-0.00182^{* * * *} \\
(0.000424)\end{array}$ \\
\hline TFP $*$ Home $\lambda$ & & & & $\begin{array}{c}1.77 \mathrm{e}-05^{* * *} \\
(3.85 \mathrm{e}-06)\end{array}$ & & & & $\begin{array}{c}0.000421 * * * \\
(9.08 \mathrm{e}-05)\end{array}$ \\
\hline Predicted probability & 0.027 & 0.027 & 0.028 & 0.028 & & & & \\
\hline Wald chi2 & 2956.11 & 3008.37 & 3123.99 & 3136.08 & 1693.02 & 1632.33 & 1762.47 & 1820.22 \\
\hline Prob > chi2 & 0.0000 & 0.0000 & 0.0000 & 0.000 & 0.0000 & 0.0000 & 0.0000 & 0.0000 \\
\hline Pseudo R2 & 0.1002 & 0.107 & 0.114 & 0.129 & & & & \\
\hline Log pseudolikelihood & $-11,232.401$ & $-11,146.437$ & $-10,006.521$ & $-9,095.128$ & $-11,053.395$ & -10.947 .974 & -9828.055 & -8961.402 \\
\hline Year dummies & Yes & Yes & Yes & Yes & Yes & Yes & Yes & Yes \\
\hline Industry dummies & Yes & Yes & Yes & Yes & Yes & Yes & Yes & Yes \\
\hline Country dummies & Yes & Yes & Yes & Yes & Yes & Yes & Yes & Yes \\
\hline Observations & 101,001 & 101,001 & 88,308 & 82,185 & 101,079 & 101,079 & 89,140 & 82,934 \\
\hline
\end{tabular}

Notes: All explanatory variables are lagged one period. All specifications include a full set of year, industry and country dummies and destinations - year pair fixed effects. Clustered standard errors are shown in parenthesis and at the parent country level for the specifications without interactions and at the parent firm-level for the other specifications. ${ }^{\star \star \star} p<0.01,{ }^{\star \star} p<0.05,{ }^{\star} p<0.1$ 
In order to identify the effect of home country employment protection more appropriately, we now report some alternative model specifications. In order to save on space, these are all based on a definition of relocation as used in Table 3a (Definition 1). ${ }^{22}$ The models in Table 4 include the vector of control variables at the firm and home country level as discussed above. The results show that the inclusion of these variables does not change our baseline findings on the importance of employment protection and its interaction with firm characteristics.

In order to check whether industry-specific characteristics drive our results, we distinguish the manufacturing sector into high- and low-tech subsectors. We present the results of re-estimating the models on the separate sub-samples in Tables 5 and 6 for low- and high-tech manufacturing sectors, respectively. Both tables show that the results on the importance of firm heterogeneity hold in both sub-sectors, albeit with some important differences. We find in both sub-sectors negative and statistically significant effects of employment protection on the probability to relocate. However, with regard to the importance of the firm-specific characteristics, we find some interesting differences.

Starting with low tech manufacturing, it is the degree of labour intensity and the size of the firm -rather than productivity- that induces firms to relocate abroad. In other words, firms that are larger and more labour intensive are more likely to relocate. This is consistent with the estimated coefficient for firms' average wage level, indicating that firms with a higher average wage are more likely to relocate. It is also in line with our theoretical model in which firms relocate in search of cheap labour and are therefore more likely to do so when they are relatively labour intensive. Importantly, we find confirmation for our hypothesis that employment protection will hinder these larger and more labour-intensive firms more than their smaller and more capital intensive counterparts, as indicated by the significantly negative coefficient on the interaction term of employment protection and size and employment protection and labour intensity.

The productivity coefficient is significant but has the opposite sign of what we expected. Here, the results in Table 3c may hint to a possible explanation for this. When we consider Definition 3 of relocation (i.e., massive layoffs associated with relocation), the random effects panel probit estimates report a highly significant negative coefficient for the lagged relocation variable, indicating that firms that relocated massively in the previous period are less likely to relocate massively in the current period. Thus, it is plausible that the most productive firms in low-tech manufacturing have been relocating earlier on and the ones that have been relocating later are the less productive ones (which would be in line with the fact that relocation has been ongoing in low-tech for quite a considerable time as the industry has been declining in the developed world).

Turning to high tech manufacturing, we find that for these sectors productivity and size are crucial in determining the propensity to relocate. Clearly, the search for cheap labour is not

\footnotetext{
${ }^{22}$ The results are consistent and similar when using Definition 2 and 3 in estimating tables 4, 5 and 6. We report further robustness checks in Appendix Tables B2 and B3 to save on space. In Table B2 we use the growth rate of EPL rather than the level. This allows us to look at within country changes in EPL over time. We find that increasing EPL affects negatively on the probability of relocation. In Table B3 we consider services sectors instead of manufacturing. This can be interpreted as a placebo test, as we argue in the paper that we expect our mechanism to work in manufacturing. We find that the link between EPL and relocation is less relevant in services, as expected.
} 


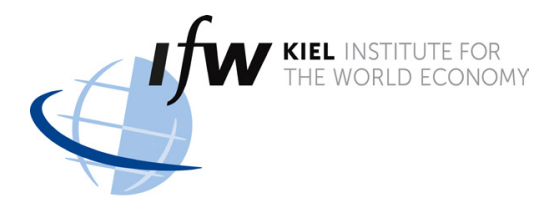

the driving force for relocation for these firms, which is reflected in the fact that the coefficient on labour intensity and average wages are negative. This suggests that, unlike in low tech manufacturing sectors, the type of labour hired by these firms is highly skilled and highly productive. In fact, in contrast to low tech manufacturing, more productive, larger firms are significantly more likely to relocate while they are also the ones that are most hampered by employment protection, which is in line with what we expected (and perhaps also reflecting that, unlike in low tech manufacturing, massive relocation is a more recent phenomenon). 


\begin{tabular}{|c|c|c|c|c|c|c|}
\hline & \multicolumn{3}{|c|}{ Probit Model (Marginal effects) } & \multicolumn{3}{|c|}{ Random Effects Panel Probit Model } \\
\hline & 1 & 2 & 3 & 4 & 5 & 6 \\
\hline Relocation (t-1) & $\begin{array}{c}0.132 * * * \\
(0.009)\end{array}$ & $\begin{array}{c}0.130 * * * \\
(0.009)\end{array}$ & $\begin{array}{c}0.128 * * * \\
(0.009)\end{array}$ & $\begin{array}{c}0.438 * * * \\
(0.0520)\end{array}$ & $\begin{array}{c}0.441 * * * \\
(0.0523)\end{array}$ & $\begin{array}{c}0.460 * * * \\
(0.0539)\end{array}$ \\
\hline Home $\lambda$ & $\begin{array}{c}-0.015^{* * *} \\
(0.004)\end{array}$ & $\begin{array}{c}-0.037^{* * *} \\
(0.004)\end{array}$ & $\begin{array}{c}-0.030 * * * \\
(0.003)\end{array}$ & $\begin{array}{l}-0.166^{* *} \\
(0.0743)\end{array}$ & $\begin{array}{c}-0.624^{* * *} \\
(0.0682)\end{array}$ & $\begin{array}{c}-0.486^{* * *} \\
(0.0523)\end{array}$ \\
\hline Size & $\begin{array}{c}0.013 * * * \\
(0.002)\end{array}$ & & & $\begin{array}{c}0.265 * * * \\
(0.0444)\end{array}$ & & \\
\hline Size $*$ Home $\lambda$ & $\begin{array}{c}-0.003 * * * \\
(0.001)\end{array}$ & & & $\begin{array}{c}-0.0556^{* * *} \\
(0.0104)\end{array}$ & & \\
\hline Labour intensity & & $\begin{array}{c}0.011 * * * \\
(0.003)\end{array}$ & & & $\begin{array}{r}0.239 * * * \\
(0.0546)\end{array}$ & \\
\hline Labour intensity ${ }^{*}$ Home $\lambda$ & & $\begin{array}{c}-0.002 * * * \\
(0.001)\end{array}$ & & & $\begin{array}{c}-0.0430 * * * \\
(0.0130)\end{array}$ & \\
\hline TFP & & & $\begin{array}{c}-5.04 \mathrm{e}-05^{* *} \\
(2.02 \mathrm{e}-05)\end{array}$ & & & $\begin{array}{c}-0.000791 \\
(0.000522)\end{array}$ \\
\hline TFP $*$ Home $\lambda$ & & & $\begin{array}{c}1.16 \mathrm{e}-05^{* * *} * \\
(4.29 \mathrm{e}-06)\end{array}$ & & & $\begin{array}{c}0.000181 \\
(0.000111)\end{array}$ \\
\hline Home tax rate & $\begin{array}{c}0.052 * * * \\
(0.016)\end{array}$ & $\begin{array}{c}0.055^{* * *} \\
(0.016)\end{array}$ & $\begin{array}{c}0.053^{* * *} \\
(0.017)\end{array}$ & $\begin{array}{c}0.879 * * * \\
(0.318)\end{array}$ & $\begin{array}{c}0.972 * * * \\
(0.317)\end{array}$ & $\begin{array}{c}0.981^{* * *} \\
(0.328)\end{array}$ \\
\hline Intangible to Total Assets & $\begin{array}{c}0.018^{* *} \\
(0.009)\end{array}$ & $\begin{array}{c}0.027^{* * *} \\
(0.008)\end{array}$ & $\begin{array}{c}0.025^{* * *} \\
(0.008)\end{array}$ & $\begin{array}{c}0.357^{* *} \\
(0.180)\end{array}$ & $\begin{array}{c}0.538^{* * *} \\
(0.177)\end{array}$ & $\begin{array}{c}0.514 * * * \\
(0.180)\end{array}$ \\
\hline Average Wage & $\begin{array}{c}3.86 \mathrm{e}-08 \\
(6.09 \mathrm{e}-07)\end{array}$ & $\begin{array}{c}2.38 \mathrm{e}-07 \\
(5.51 \mathrm{e}-07)\end{array}$ & $\begin{array}{l}-1.06 e-07 \\
(5.13 e-07)\end{array}$ & $\begin{array}{c}-6.80 \mathrm{e}-06 \\
(1.85 \mathrm{e}-05)\end{array}$ & $\begin{array}{l}-8.89 \mathrm{e}-07 \\
(1.68 \mathrm{e}-05)\end{array}$ & $\begin{array}{c}-6.14 \mathrm{e}-06 \\
(1.97 \mathrm{e}-05)\end{array}$ \\
\hline Predicted probability & 0.028 & 0.028 & 0.027 & & & \\
\hline Wald chi2 & $2,494.40$ & $2,408.92$ & $2,427.29$ & $1,020.09$ & $1,015.92$ & $1,014.84$ \\
\hline Prob > chi2 & 0.000 & 0.000 & 0.000 & 0.0000 & 0.0000 & 0.0000 \\
\hline Pseudo R2 & 0.107 & 0.106 & 0.111 & & & \\
\hline Log pseudolikelihood & $-9,235.699$ & $-9,131.732$ & $-8,502.499$ & $-9,136.2052$ & $-9,036.2858$ & $-8,424.5042$ \\
\hline Observations & 62,052 & 61,554 & 57,927 & 61,861 & 61,366 & 57,800 \\
\hline
\end{tabular}

Notes: Coefficients are shown as marginal effects. All explanatory variables are lagged one period. All specifications include a full set of year, industry and country dummies and destinations - year pair fixed effects. Clustered standard errors are shown in parenthesis and at the parent country level for the specifications without interactions and at the parent firm-level for the other specifications. ; ${ }^{* * *} p<0.01,{ }^{* *} p<0.05,{ }^{*} p<0.1$ 
Table 5: Low-technology sector

\begin{tabular}{|c|c|c|c|c|c|c|}
\hline & \multicolumn{3}{|c|}{ Probit Model (Marginal effects) } & \multicolumn{3}{|c|}{ Random Effects Panel Probit Model } \\
\hline & 1 & 2 & 3 & 4 & 5 & 6 \\
\hline \multirow[t]{2}{*}{ Relocation $(\mathrm{t}-1)$} & $0.119 * * *$ & $0.115 * * *$ & $0.113^{* * *}$ & $0.263 * * *$ & $0.264^{* * *}$ & $0.278 * * *$ \\
\hline & $(0.012)$ & $(0.012)$ & $(0.012)$ & $(0.0729)$ & $(0.0736)$ & $(0.0768)$ \\
\hline \multirow[t]{2}{*}{ Home $\lambda$} & $-0.017 * *$ & $-0.052 * * *$ & $-0.031 * * *$ & -0.115 & $-0.836 * * *$ & $-0.438 * * *$ \\
\hline & $(0.006)$ & $(0.005)$ & $(0.004)$ & $(0.103)$ & $(0.102)$ & $(0.0717)$ \\
\hline \multirow[t]{2}{*}{ Size } & $0.011 * * *$ & & & $0.258 * * *$ & & \\
\hline & $(0.003)$ & & & $(0.0609)$ & & \\
\hline \multirow[t]{2}{*}{ Size $*$ Home $\lambda$} & $-0.003 * * *$ & & & $-0.0572 * * *$ & & \\
\hline & $(0.001)$ & & & $(0.0144)$ & & \\
\hline \multirow[t]{2}{*}{ Labour intensity } & & $0.029 * * *$ & & & $0.576 * * *$ & \\
\hline & & $(0.004)$ & & & $(0.0869)$ & \\
\hline \multirow[t]{2}{*}{ Labour intensity $*$ Home $\lambda$} & & $-0.006 * * *$ & & & $-0.111 * * *$ & \\
\hline & & $(0.001)$ & & & $(0.0203)$ & \\
\hline \multirow[t]{2}{*}{ TFP } & & & $-8.20 \mathrm{e}-05^{* * *}$ & & & $-0.00147^{* *}$ \\
\hline & & & $(2.74 \mathrm{e}-05)$ & & & $(0.000632)$ \\
\hline \multirow[t]{2}{*}{ TFP $*$ Home $\lambda$} & & & $1.78 \mathrm{e}-05^{* * *}$ & & & $0.000317^{* *}$ \\
\hline & & & $(5.54 \mathrm{e}-06)$ & & & $(0.000134)$ \\
\hline \multirow[t]{2}{*}{ Home tax rate } & $0.073^{* * *}$ & $0.077^{* * *}$ & $0.074 * * *$ & $1.132 * * *$ & $1.284^{* * *}$ & $1.190 * * *$ \\
\hline & $(0.019)$ & $(0.019)$ & $(0.020)$ & $(0.417)$ & $(0.418)$ & $(0.429)$ \\
\hline \multirow[t]{2}{*}{ Intangible to Total Assets } & 0.005 & $0.022^{*}$ & 0.014 & 0.120 & 0.398 & 0.308 \\
\hline & $(0.014)$ & $(0.013)$ & $(0.014)$ & $(0.298)$ & (0.293) & $(0.301)$ \\
\hline \multirow[t]{2}{*}{ Average Wage } & $7.68 \mathrm{e}-06^{* * *}$ & $9.42 \mathrm{e}-06^{* * *}$ & $7.52 \mathrm{e}-06^{* * *}$ & $0.000124 * * *$ & $0.000170^{* * *}$ & $0.000141^{* *}$ \\
\hline & $(2.47 e-06)$ & $(2.47 \mathrm{e}-06)$ & $(2.59 \mathrm{e}-06)$ & $(4.80 \mathrm{e}-05)$ & (4.89e-05) & $(5.89 \mathrm{e}-05)$ \\
\hline Predicted probability & 0.030 & 0.030 & 0.030 & & & \\
\hline Wald chi2 & $1,309.74$ & $1,346.66$ & $1,306.43$ & 475.44 & 516.00 & 468.83 \\
\hline Prob > chi2 & 0.000 & 0.000 & 0.000 & 0.0000 & 0.0000 & 0.0000 \\
\hline Pseudo R2 & 0.101 & 0.107 & 0.106 & & & \\
\hline Log pseudolikelihood & $-4,966.972$ & $-4,883.143$ & $-4,477.742$ & $-4,435.795$ & $-4,829.0268$ & $-4,904.2686$ \\
\hline Observations & 32,162 & 31,897 & 29,455 & 30,053 & 32,202 & 32,472 \\
\hline
\end{tabular}

Notes: Coefficients are shown as marginal effects. All explanatory variables are lagged one period. All specifications include a full set of year, industry and country dummies and destinations year pair fixed effects. Clustered standard errors are shown in parenthesis and at the parent country level for the specifications without interactions and at the parent firm-level for the other specifications. ; ${ }^{* \star *} p<0.01,{ }^{* *} p<0.05,{ }^{*} p<0.1$ 
Table 6: High-technology sector

\begin{tabular}{|c|c|c|c|c|c|c|}
\hline & \multicolumn{3}{|c|}{ Probit Model (Marginal effects) } & \multicolumn{3}{|c|}{ Random Effects Panel Probit Model } \\
\hline & 1 & 2 & 3 & 4 & 5 & 6 \\
\hline \multirow[t]{2}{*}{ Relocation $(\mathrm{t}-1)$} & $0.122 * * *$ & $0.120 * * *$ & $0.127 * * *$ & $0.698 * * *$ & $0.690 * * *$ & $0.716^{* * *}$ \\
\hline & $(0.014)$ & $(0.014)$ & $(0.013)$ & $(0.0740)$ & $(0.0745)$ & $(0.0771)$ \\
\hline \multirow[t]{2}{*}{ Home $\lambda$} & $-0.008 *$ & $-0.015^{* * *}$ & $-0.016 * * *$ & $-0.200 *$ & $-0.464 * * *$ & $-0.446 * * *$ \\
\hline & $(0.005)$ & $(0.005)$ & $(0.004)$ & $(0.115)$ & $(0.102)$ & $(0.0855)$ \\
\hline \multirow[t]{2}{*}{ Size } & $0.011 * * *$ & & & $0.283 * * *$ & & \\
\hline & $(0.003)$ & & & $(0.0682)$ & & \\
\hline \multirow[t]{2}{*}{ Size $*$ Home $\lambda$} & $-0.002 * * *$ & & & $-0.0568 * * *$ & & \\
\hline & $(0.001)$ & & & $(0.0159)$ & & \\
\hline \multirow[t]{2}{*}{ Labour intensity } & & -0.004 & & & -0.0414 & \\
\hline & & $(0.003)$ & & & $(0.0802)$ & \\
\hline \multirow[t]{2}{*}{ Labour intensity *Home $\lambda$} & & 0.001 & & & 0.0128 & \\
\hline & & $(0.001)$ & & & $(0.0192)$ & \\
\hline \multirow[t]{2}{*}{ TFP } & & & $7.43 e-05 * *$ & & & $0.00232 * *$ \\
\hline & & & $(3.16 e-05)$ & & & $(0.00106)$ \\
\hline \multirow[t]{2}{*}{ TFP $*$ Home $\lambda$} & & & $-1.49 e-05^{* *}$ & & & $-0.000474 * *$ \\
\hline & & & $(6.91 \mathrm{e}-06)$ & & & $(0.000232)$ \\
\hline \multirow[t]{2}{*}{ Home tax rate } & 0.015 & 0.012 & 0.018 & 0.660 & 0.628 & 0.892 \\
\hline & $(0.021)$ & $(0.021)$ & $(0.023)$ & (0.589) & $(0.590)$ & $(0.612)$ \\
\hline \multirow[t]{2}{*}{ Intangible to Total Assets } & $0.020 * *$ & $0.022 * * *$ & $0.024 * * *$ & $0.485^{* *}$ & $0.594^{* * *}$ & $0.650 * * *$ \\
\hline & $(0.008)$ & $(0.008)$ & $(0.007)$ & $(0.228)$ & $(0.226)$ & $(0.231)$ \\
\hline \multirow[t]{2}{*}{ Average Wage } & $-1.54-05^{* *}$ & $-1.55 e-04 * *$ & $-3.44-04 * * *$ & $-0.00494 * * *$ & $-0.00483^{* * *}$ & $-0.0108 * * *$ \\
\hline & $(4.21 \mathrm{e}-05)$ & $(4.20 \mathrm{e}-05)$ & $(3.67 e-05)$ & $(0.00100)$ & $(0.00103)$ & $(0.00147)$ \\
\hline Predicted probability & 0.039 & 0.039 & 0.039 & & & \\
\hline Wald chi2 & $1,574.950$ & $1,551.74$ & $1,514.780$ & 743.53 & 729.99 & 750.61 \\
\hline Prob > chi2 & 0.000 & 0.000 & 0.000 & 0.000 & 0.000 & 0.000 \\
\hline Pseudo R2 & 0.148 & 0.143 & 0.152 & & & \\
\hline Log pseudolikelihood & $-4,065.768$ & $-4,023.092$ & $-3,805.453$ & $-3,840.134$ & -4056.391 & $-4,100.501$ \\
\hline Observations & 28,759 & 28,532 & 26,822 & 27,747 & 29,164 & 29,389 \\
\hline
\end{tabular}

Notes: Coefficients are shown as marginal effects. All explanatory variables are lagged one period. All specifications include a full set of year, industry and country dummies and destinations year pair fixed effects. Clustered standard errors are shown in parenthesis and at the parent country level for the specifications without interactions and at the parent firm-level for the other specifications. ; ${ }^{* * *} p<0.01,{ }^{* *} p<0.05,{ }^{*} p<0.1$ 


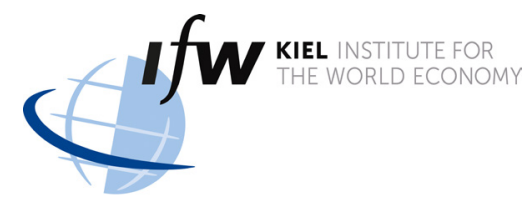

\section{CONCLUSIONS}

This paper examines the determinants of the decision to relocate activities abroad for MNEs that are located in 28 OECD countries. Particular attention is paid to home-country employment protection as a barrier to exit. For high and low-tech manufacturing sectors we find that stricter employment protection in the home country discourages firms' relocation. Highly labour intensive firms in low-skill manufacturing and large, highly productive firms in high-skill manufacturing have, ceteris paribus, higher propensities to relocate. Precisely these firms are, as suggested by our theoretical framework, hampered most in their relocation decisions by home country employment protection.

Overall, our theoretical and empirical analysis suggests that the relationship between labour market rigidities and FDI is more complex than generally postulated in the literature. In particular, we show that employment protection in the current country of location matters, while most earlier work focuses on what happens in the prospective host country. From a policy point of view, our results suggest that countries with strict employment protection may be in a stronger position to slow down the exit of large, productive and highly labour intensive firms than their counterparts with lax employment protection laws. This may be a blessing or a curse. Hindering firms to relocate abroad prevents them from enjoying the benefits of such relocation in terms of better productivity or competitiveness. However, there may undoubtedly also be social adjustment costs that are potentially associated with industry relocation. 


\section{REFERENCES}

Amiti, M. and K. Wakelin (2003). Investment liberalization and international trade, Journal of International Economics, 61, 101-126.

Amiti, M. and S. Wei (2005). Fear of service outsourcing: is it justified?, Economic Policy, 20: 308-347.

Aw, B.Y. and Y. Lee (2008). Firm heterogeneity and location choice of Taiwanese multinationals, Journal of International Economics, 76: 403-415.

Barba-Navaretti, G. and A. Venables (2004). Multinational Firms in the World Economy, Princeton University Press.

Belot, M., J. Boone and J. Van Ours (2007). Welfare-Improving Employment Protection. Economica, 74: 381-396

Bertola, G., and R. Rogerson (1997). Institutions and labor reallocation, European Economic Review, 41: 11471171.

Bertola, G., A. Dabusinskas, M. Hoeberichts, M. Izquierdo, C. Kwapil, J. Montornès and D. Radowski (2010). Price, Wage and Employment Response to Shocks. Evidence from the WDN Survey, ECB Wage Dynamics Network, Working paper No 1164.

Bhagwati, J. and A. Blinder (2009). Offshoring of American Jobs: What Response from US Economic Policy?, MIT Press: Cambridge, MA.

Blinder, A.( 2007). Offshoring: Big Deal, or Business as Usual?, CEPS Working Paper No. 149.

Blonigen, B.A. (2005). A review of the empirical literature on FDI determinants, Atlantic Economic Journal, 33: 383-403.

Cohen, D. (2006). Globalization and employment, in Auer, P., G. Besse and D. Méda (Eds.), Offshoring and the Internationalization of Employment. A Challenge for a Fair Globalization, International Labour Organization, 17-36.

Chen, M. and M. Moore (2010). Location decision of heterogeneous multinational firms, Journal of International Economics, 80: 188-199.

De Mooij, R. and S Ederveen (2003). Taxation and foreign direct investment: A synthesis of empirical research, International Tax and Public Finance, 10: 673-693.

Desai, M., P.A. Gompers and J. Lerner (2003). Institutions, Capital Constraints and Entrepreneurial Firm Dynamics: Evidence from Europe, NBER working paper No. 10165.

Dewit, G., H. Görg and C. Montagna (2009). Should I stay or should I go? Foreign direct investment, employment protection and domestic anchorage, Review of World Economics, 145: 93-110.

Dewit, G., D. Leahy and C. Montagna (2013). Employment protection, flexibility and firms' strategic location choices under uncertainty, Economica, 80: 441-474.

Di Tella, R. and R. MacCulloch (2005). The consequences of labor market flexibility: Panel evidence based on survey data, European Economic Review, 49: 1225-1259.

European Commission (2012). Reaping the Benefits of Globalization, European Competitiveness Report 2012.

European Parliament (2007). Delocalisation of EU Industry. Delocalisation and the challenge of structural adjustment. A review of policy options, European Parliament's committee on Industry, Research and Energy.

Eurostat (2014) Eurostat indicators of High-tech industry and knowledge-intensive services. Available http://epp.eurostat.ec.europa.eu/cache/ITY_SDDS/Annexes/htec_esms_an3.pdf

Garibaldi, P. (1998). Job flow dynamics and firing restrictions, European Economic Review, 42, No. 2: 245-75.

Gerosky, P., R. Gilbert and A. Jacquemin (1990). Barriers to Entry and Strategic Competition, Harwood Academic Publishers.

Görg, H. (2005). Fancy a stay at the "Hotel California"? The role of easy entry and exit for FDI, Kyklos, 58: 519535

Haaland, J.I., I. Wooton and G. Faggio (2003). Multinational firms: Easy come, easy go?, FinanzArchiv 59: 3-26. 
Harrison, A. and M. McMillan (2011). Offshoring Jobs? Multinationals and U.S. Manufacturing Employment, Review of Economics and Statistics, 93: 857-875.

Helpman, E., M. Melitz and S. Yeaple (2004). Export versus FDI with heterogeneous firms, American Economic Review, 94: 300-316.

Hijzen, A., S. Jean and T. Mayer (2011). The effects at home of initiating production abroad: evidence from matched French firms, Review of World Economics, 147: 457-483

Jabobson, L.S., R.J. LaLonde, and D.G. Sullivan (1993). Earnings Losses of Displaces Workers, American Economic Review, 83(4): 685-709.

Javorcik, B.S. and M. Spatareanu (2005). Do foreign investors care about labor market regulations? Review of World Economics, 141: 375-403.

Klapper, L., L. Laeven, and R. Rajan (2004). Business Environment and Firm Entry: Evidence from International Data, NBER working paper No. 10380.

Levinsohn, J. and A. Petrin (2003). Estimating production functions using inputs to control for observables, Review of Economic Studies, 70: 317-341.

Markusen, J. R. (1995). The Boundaries of Multinational Enterprises and the Theory of International Trade, Journal of Economic Perspectives 9(2): 169-89.

Messina, J. and G. Vallanti (2007). Job flow dynamics and firing restrictions: Evidence from Europe, The Economic Journal, 117: F279-F301.

Midelfart-Knarvik, K., H. Overman, P. Lane and J.-M. Viaene (2002). Delocation and European integration: Is structural spending justified?, Economic Policy, 17: 321-359.

Motta, M, and J. Thisse (1994). Does environmental dumping lead to delocation, European Economic Review, 38 : 563-576.

Muendler, M.A. and S.O. Becker (2010). Margins of Multinational Labor Substitution, American Economic Review, 100(5): 1999-2030.

Nicoletti, G., S. Golub, D. Hajkova, D. Mirza, G. and K. Yoo (2003). The Influence of Policies on Trade and Foreign Direct Investment, OECD Economic Studies, No. 36.

Olney, W. (2013). A race to the bottom? Employment protection and foreign direct investment, Journal of International Economics, 91(2): 191-203.

Pennings, E. and L. Sleuwaegen (2000). International relocation: firm and industry determinants, Economics Letters, 67: 179-186.

Pennings, E. and L. Sleuwaegen (2006). International relocation of production: Where do firms go?", Scottish Journal of Political Economy, 53: 430-446.

Stigler, G. (1968). The Organization of Industry, University of Chicago Press, 328 p.

Wooldridge, J.M. (2005). Simple solutions to the initial conditions problem in dynamic, nonlinear panel data models with unobserved heterogeneity. Journal of Applied Econometrics, 20(1): 39-54. 


\section{APPENDIX A - THEORETICAL APPENDIX}

\section{(i) Deriving optimal outputs}

The optimal period-two output level when the firm decides to relocate to $F$, obtained from maximising expression (4a) with respect to $q_{2}^{F}$, is given by:

$q_{2}^{F}=\left[a-c_{2}^{F}\right] / 2$

while the optimal period-two output when the firm decides to stay in $H$ is obtained from maximising expression (4b) with respect to $q_{2}^{H}$ and is:

$q_{2}^{H}=\left[a-c^{H}+I \lambda^{H} \alpha_{l}\right] / 2$

Using expressions (A.1a) and (A.1b), the relocation condition (expression (3)) becomes:

$\left[\left(a-c_{2}^{F}\right)^{2}-\left(a-c^{H}+I \lambda^{H} a_{l}\right)^{2}\right] / 4>\Phi^{F}+(1-I) \lambda^{H} \alpha_{l} q_{1}^{H}$.

The firm determines its optimal period-one output level by maximising expected profit $(E \pi)$, with:

$E \pi=\pi_{1}+\rho \pi_{2}\left(H_{1}, H_{2}\right)+(1-\rho) \pi_{2}\left(H_{1}, F_{2}\right)$

and $\pi_{1}=\left(p_{1}-c^{H}\right) q_{1}^{H}$. Maximising expression (A.3) with respect to $q_{1}^{H}$ yields:

$q_{1}^{H}=\left[a-c^{H}-(1-\rho) \lambda^{H} \alpha_{l}-I \rho \lambda^{H} \alpha_{l}\right] / 2$.

From (A.4) and (A.1b), $q_{1}^{H}<q_{2}^{H}$ follows; hence $I=0$ in (A.1b), (A.2) and (A.4). Expression (A.6) shows that the firm takes into account that it may want to relocate in period two by restricting its period-one output somewhat (reflected by $-(1-\rho) \lambda^{H} \alpha_{l} / 2$ ) in order to limit future exit costs in case of relocation. ${ }^{23}$

\section{(ii) Comparative statics}

Using comparative statics, we examine how a firm's propensity to relocate is affected by a change in firm size, productivity and labour intensity. Define $A^{H} \equiv a-c^{H}$ and $A_{2}^{F} \equiv a-c_{2}^{F}=\theta A^{H}$ with $\theta>1$ (since $c_{2}^{F}<c^{H}$, and hence $A_{2}^{F}>A^{H}$, is a necessary condition for relocation). $A^{H}$ can be interpreted as a determinant of firm size. Also, since $A^{H}$ is inversely related to the average variable cost of production, $A^{H}$ could, alternatively, be viewed as an indicator of firm productivity. Using $A_{2}^{F}=\theta A^{H}$, the derivative of the left-hand side of expression (5) with respect to $A^{H}$ is equal to $\left[A^{H} / 2\right]\left(\theta^{2}-1\right)>0$. So, when $\lambda^{H}=0$, larger -more productive- firms have a higher propensity to relocate. However, when $\lambda^{H}>0$, the

\footnotetext{
${ }^{23}$ We have $d\left(\lambda^{H} \alpha_{l} q_{1}^{H}\right) / d \lambda^{H}>0$ provided that the probability of relocation is not too high compared to the first-period output of the firm (i.e., $\left.1-\rho<\left(a-c^{H}\right) / 2 \lambda^{H} \alpha_{l}\right)$. We assume this to be the case to ensure the firm wanted to produce in $H$ as its initial location.
} 
propensity to relocate of firms located in $H$ will be lower. With $I=0$ in expression (5), EPLinduced exit costs are represented by $\lambda^{H} \alpha_{l} q_{1}^{H}$. We have $d\left(\lambda^{H} \alpha_{l} q_{1}^{H}\right) / d A^{H}=\lambda^{H} \alpha_{l} / 2>0$. So, ceteris paribus, larger and more productive firms have higher exit costs from a country with high employment protection than their smaller and less productive counterparts, which mitigate their relatively higher potential gains from relocation. It suggests that employment protection tends to narrow the differences in the propensity to relocate between large and small firms and between very productive and less productive firms.

Next, we look at the effect of labour intensity on a firm's propensity to relocate. To isolate the labour intensity from the firm productivity effect, we compare the propensity to relocate for home firms that are equally productive, or, have the same marginal production costs $\left(c^{H}\right)$-and, in our model, thus have the same size, $A^{H}$-, but operate with different relative labour intensities (denoted by $\left.l / k=\alpha_{l} / \alpha_{k}\right)$. An increase in firm-specific labour intensity that leaves $c^{H}$ unaffected means $d c^{H} / d \alpha_{l}=w^{H}+\left(d \alpha_{k} / d \alpha_{l}\right) r^{H}=0$, which in turn implies $d \alpha_{k} / d \alpha_{l}=-w^{H} / r^{H}$. We first determine how such an increase in relative labour intensity of the firm affects its potential gains from relocation. Differentiating the left-hand side of the inequality in expression (5) with respect to $\alpha_{l}$ (while keeping $c^{H}$ constant) yields $-A_{2}^{F}\left[w_{2}^{F}-r^{F}\left(w^{H} / r^{H}\right)\right] / 2$. Since $w_{2}^{F} / r^{F}<w^{H} / r^{H}$, we have $w_{2}^{F}-r^{F}\left(w^{H} / r^{H}\right)<0$, and thus $-A_{2}^{F}\left[w_{2}^{F}-r^{F}\left(w^{H} / r^{H}\right)\right] / 2>0$, meaning that the gain of relocation towards countries in which labour is relatively cheap is higher for more labour intensive firms. But, employment protection in the country from where the firm considers relocation raises exit costs $\left(\lambda^{H} \alpha_{l} q_{1}^{H}\right)$, which are higher the more labour intensive the firm is (i.e., the higher $\alpha_{l}$ ). So, among equally productive, equally-sized firms, we expect that highly labour-intensive firms gain most from relocation, while at the same time being hindered most in their relocation decision if they face high levels of employment protection in the country from which they consider relocation. Thus, we expect that the difference in relocation propensity between firms with a high and a low labour intensity will be narrowed by employment protection. 


\section{APPENDIX B - EMPIRICAL APPENDIX}

\section{Variable definitions:}

Firm size is measured using the natural logarithm of employees (Source: ORBIS)

Home $\lambda$ is the Employment protection index observed in the source country (Source: World Economic Forum)

Labour intensity is measured as the natural logarithm of the ratio of labour to capital, where capital is measured by fixed assets (Source: ORBIS)

Average Wage is calculated by dividing a firm's total wage bill by the number of employees (Source: ORBIS)

Total factor productivity estimated using the approach described in Levinsohn and Petrin (2003)

IATA is calculated as the ratio of intangible assets over total assets (Source: ORBIS)

Rates of tax on income, profits and corporate gains (Source: World Economic Forum) 


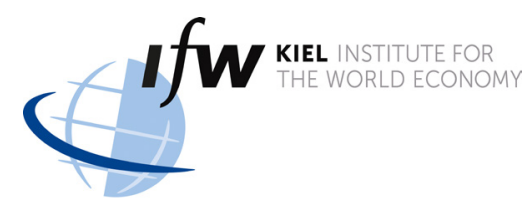

\section{Classification of manufacturing industries by level of technology intensity:}

Eurostat uses the following aggregation according to technological-intensity and based on NACE Rev. 1 at the 2-digit level. Table A1 shows this classification for the manufacturing sector related to high-technology and low-technology.

Table B1: Manufacturing industries by level of technology intensity

\begin{tabular}{|c|c|}
\hline Level of technology intensity & NACE two digits code (Divisions) \\
\hline \multirow[t]{3}{*}{ High-technology sectors } & $\begin{array}{l}\text { Manufacture of office machinery and computers }(30) \text {; } \\
\text { Manufacture of radio, television and communication equipment } \\
\text { and apparatus(32); }\end{array}$ \\
\hline & $\begin{array}{l}\text { Manufacture of medical, precision and optical instruments, } \\
\text { watches and clocks (33) }\end{array}$ \\
\hline & $\begin{array}{l}\text { Manufacture of electrical machinery and apparatus n.e.c. (31); } \\
\text { Manufacture of motor vehicles, trailers and semi-trailers (34); } \\
\text { Manufacture of chemicals and chemical products (24); } \\
\text { Manufacture of machinery and equipment n.e.c. (29); } \\
\text { Manufacture of other transport equipment (35) }\end{array}$ \\
\hline \multirow[t]{6}{*}{ Low technology sectors } & $\begin{array}{l}\text { Manufacture of coke, refined petroleum products and nuclear } \\
\text { fuel (23); Manufacture of rubber and plastic products } \\
\text { Manufacture of other non-metallic mineral products } \\
\text { Manufacture of basic metals (27); Manufacture of fabricated } \\
\text { metal products, except machinery and equipment (28) }\end{array}$ \\
\hline & Manufacture of food products and beverages (15); \\
\hline & $\begin{array}{l}\text { Manufacture of tobacco products (16); Manufacture of textiles } \\
\text { (17); Manufacture of wearing apparel; dressing and dyeing of } \\
\text { fur (18); Tanning and dressing of leather; manufacture of } \\
\text { luggage, handbags, saddlery, harness and footwear (19); }\end{array}$ \\
\hline & $\begin{array}{l}\text { Manufacture of wood and of products of wood and cork, except } \\
\text { furniture; manufacture of articles of straw and plaiting } \\
\text { materials (20); Manufacture of pulp, paper and paper products } \\
\text { (21); Publishing, printing and reproduction of recorded media } \\
\text { (22); }\end{array}$ \\
\hline & Manufacture of furniture; manufacturing n.e.c. (36) \\
\hline & Recycling (37) \\
\hline
\end{tabular}

Source: Eurostat (2014) 


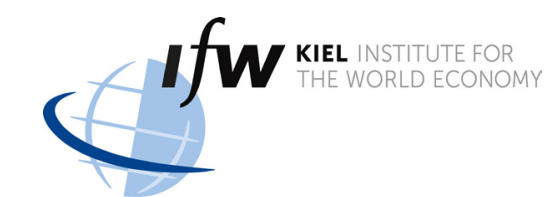

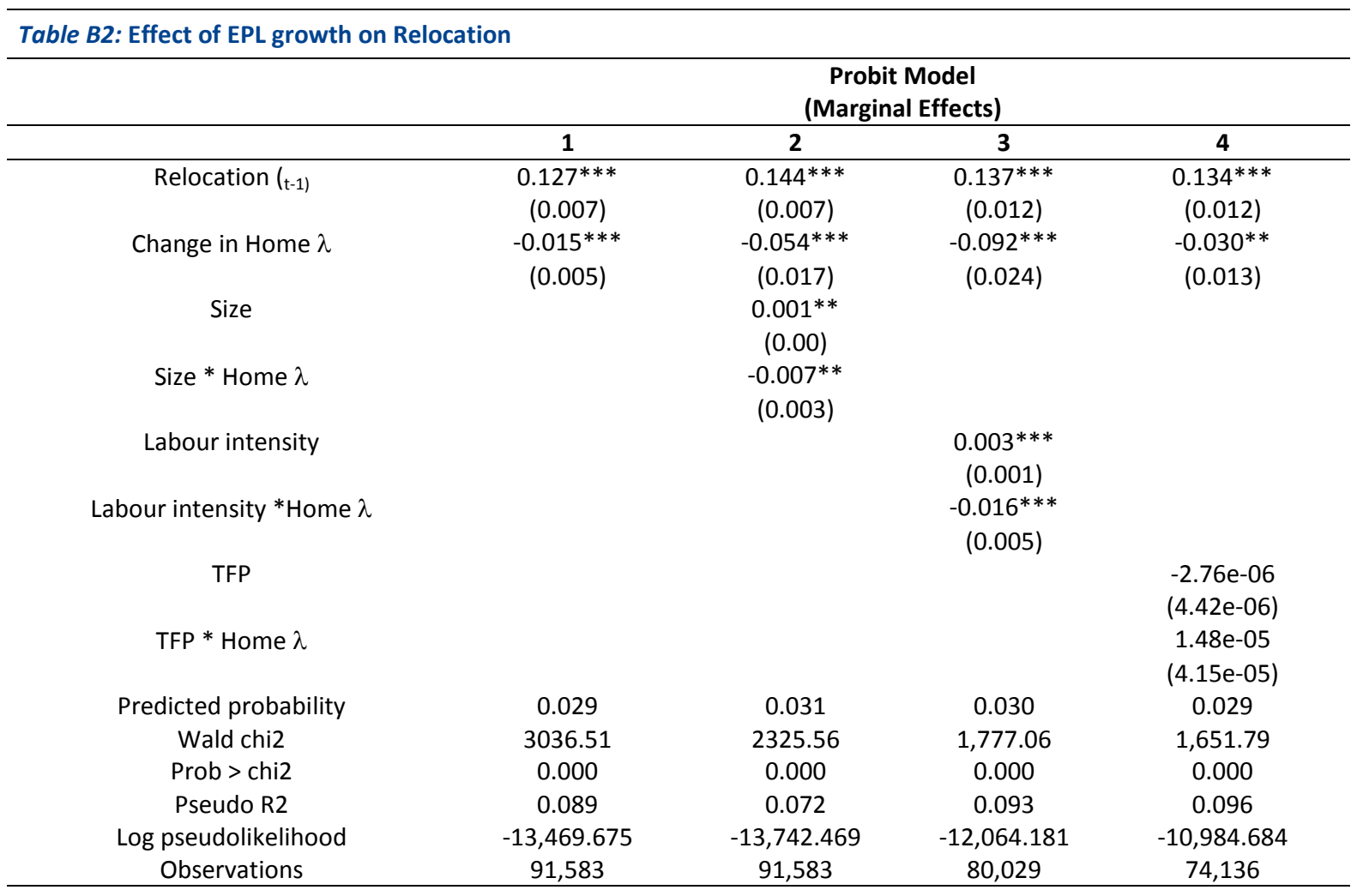

Notes: Coefficients are shown as marginal effects. All explanatory variables are lagged one period. All specifications include a full set of year, industry and country dummies and destination-time pair fixed effects. Clustered standard errors are shown in parenthesis and at the parent country level for the specifications without interactions and at the parent firm-level for the other specifications. ${ }^{* * *} p<0.01, * * p<0.05,{ }^{*} p<0.1$ 


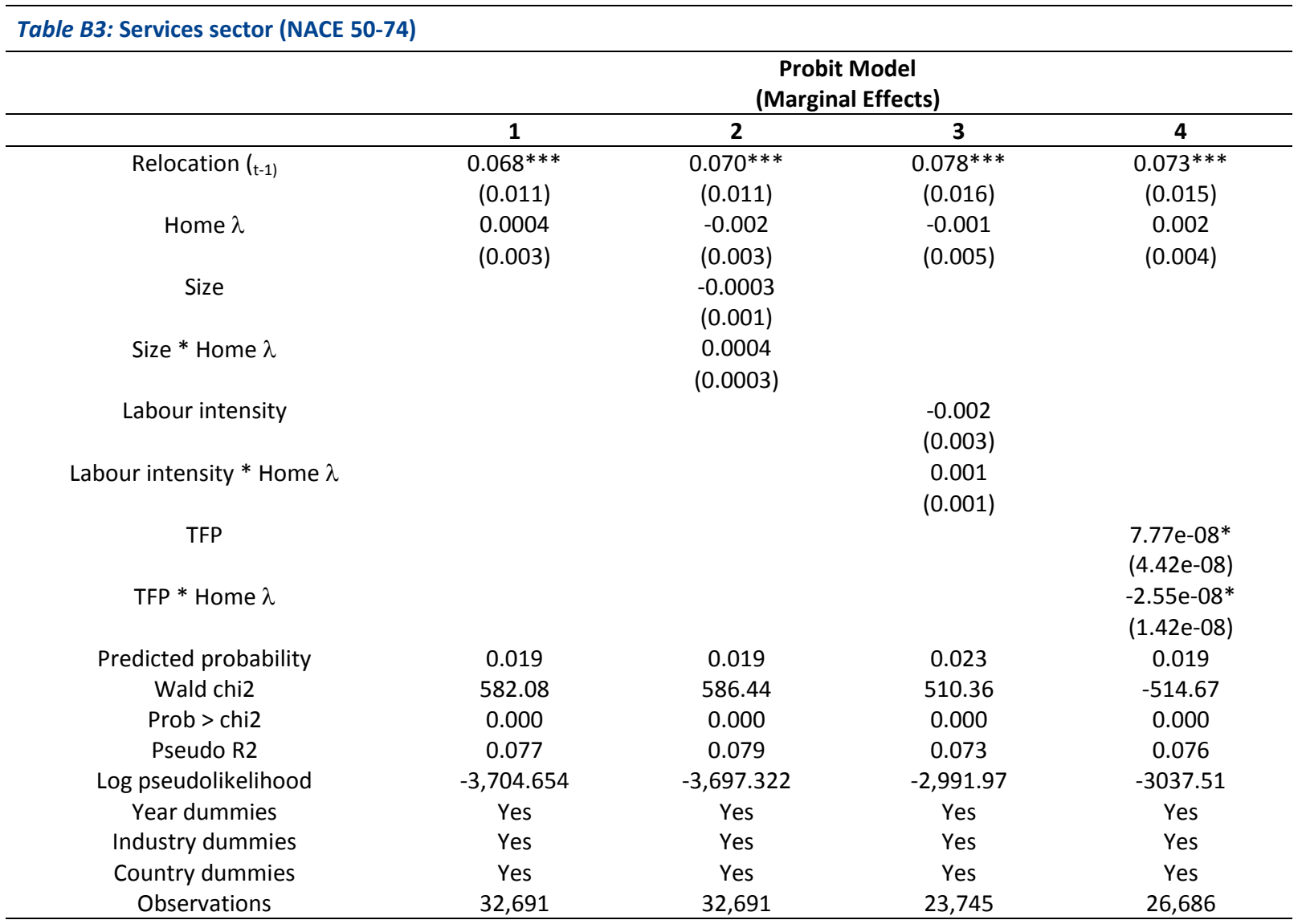

Notes: Coefficients are shown as marginal effects. All explanatory variables are lagged one period. All specifications include a full set of year, industry and country dummies. Clustered standard errors are shown in parenthesis and at the parent country level for the specifications without interactions and at the parent firm-level for the other specifications. ${ }^{* * *} p<0.01$, $* * p<0.05, * p<0$. 